\title{
Quantifying the Surface-Subsurface Biogeochemical Coupling During the VERTIGO ALOHA and K2 Studies
}

Philip W. Boyd ${ }^{1}$, Mark P. Gall ${ }^{2}$, Mary W. Silver ${ }^{3}$, Susan L. Coale ${ }^{3}$, Robert R. Bidigare ${ }^{4}$, and James K.B. Bishop ${ }^{5}$

\footnotetext{
${ }^{1}$ National Institute of Water and Atmospheric Research, Centre for Chemical and Physical Oceanography, Department of Chemistry, PO Box 56, Dunedin, New Zealand

${ }^{2}$ National Institute of Water and Atmospheric Research, Christchurch, New Zealand

${ }^{3}$ Institute of Marine Sciences, University of California, Santa Cruz, CA, USA

${ }^{4}$ Hawai`i Institute of Marine Biology, University of Hawai‘I, P.O. Box 1346, Kane`ohe, HI 96744, USA

${ }^{5}$ Lawrence Berkeley National Laboratory, 1 Cyclotron Road, Berkeley, CA 94720, USA
}

February 25, 2008 
Abstract A central question addressed by the VERTIGO (VERtical Transport In the Global Ocean) study was 'What controls the efficiency of particle export between the surface and subsurface ocean'? Here, we present data from sites at ALOHA (N Central Pacific Gyre) and K2 (NW subarctic Pacific) on phytoplankton processes, and relate them via a simple planktonic foodweb model, to subsurface particle export (150-500 m). Three key factors enable quantification of the surface-subsurface coupling: a sampling design to overcome the temporal lag and spatial displacement between surface and subsurface processes; data on the size-partitioning of Net Primary Production (NPP) and subsequent transformations prior to export; estimates of the ratio of algal- to faecalmediated vertical export flux. At ALOHA, phytoplankton were characterized by low stocks, NPP, $\mathrm{F}_{\mathrm{v}} / \mathrm{F}_{\mathrm{m}}$ (N-limited), and were dominated by picoplankton. The HNLC waters at K2 were characterized by both two-fold changes in NPP and floristic shifts (high to low proportion of diatoms) between deployment 1 and 2. Prediction of export exiting the euphotic zone was based on size-partitioning of NPP, a copepod-dominated foodweb and a ratio of 0.2 (ALOHA) and 0.1 (K2) for algal:faecal particle flux. Predicted export was 20-22 mg POC $\mathrm{m}^{-2} \mathrm{~d}^{-1}$ at ALOHA (i.e. 10-11\% NPP (0-125 m); 1.1-1.2 x export flux at $150 \mathrm{~m}\left(\mathrm{E}_{150}\right)$. At K2, export was $111 \mathrm{mg} \mathrm{C} \mathrm{m}^{-2} \mathrm{~d}^{-1}$ (21\% NPP (0-50 m); $\left.1.8 \times \mathrm{E}_{150}\right)$ and $33 \mathrm{mg}$ POC $\left.\mathrm{m}^{-2} \mathrm{~d}^{-1}(11 \% \mathrm{NPP}, 0-55 \mathrm{~m}) ; 1.4 \mathrm{x} \mathrm{E}_{150}\right)$ for deployments 1 and 2, respectively. This decrease in predicted export at K2 matches the observed trend for $\mathrm{E}_{150}$. Also, the low attenuation of export flux from 60 to $150 \mathrm{~m}$ is consistent with that between 150 to $500 \mathrm{~m}$. This strong surface-subsurface coupling suggests that phytoplankton productivity and floristics play a key role at K2 in setting export flux, and moreover that pelagic 
particle transformations by grazers strongly influence to what extent sinking particles are further broken down in the underlying waters of the Twilight Zone.

\section{Introduction}

The biological pump is one of several (such as the solubility pump) that sequester carbon to the oceans interior (Volk and Hoffert, 1985). The source of particles, for the biological pump, is primary production within the euphotic zone. Here, phytoplankton may exit both directly, for example as sinking algal aggregates (Lampitt, 1985), and indirectly, for example settling faecal pellets produced during herbivory (Small et al., 1983; Lampitt et al., 1993). The main region for particle production is often within and/or just below the euphotic zone (Buesseler et al., 2001; Pike et al., 2006). Quantification of this link between the surface ocean and the ocean's interior has therefore been the focus of many studies.

Early approaches to examine this biogeochemical coupling were restricted to surface waters and the deep ocean. They investigated the nature of the relationship between Net Primary Production (NPP) and downward export fluxes of Particulate Organic Carbon (POC) into deep-moored sediment traps (Suess, 1980; Pace et al., 1987). Subsequent studies focussed on a comparison between $\mathrm{J}_{100}$ (an integral of particle transformations at $100 \mathrm{~m}$ depth) and export fluxes obtained from surface-tethered free-drifting trap arrays and/or deep-moored trap time-series (Martin et al., 1987; Bender et al., 1992). The use of $\mathrm{J}_{100}$, rather than NPP, resulted in a more robust relationship with downward export fluxes (Bishop, 1989). The accuracy of export fluxes derived from traps deployed at shallower than $1 \mathrm{~km}$ depth was subsequently questioned (Yu, 1994), leading to more emphasis on downward POC export derived from Thorium-Uranium disequilibria in conjunction with 
C:Th particulate ratios (Buesseler, 1998). This enabled the comparison of the ratio of NPP to Thorium-derived POC export fluxes (see ThE ratio in Buesseler 1998).

During this period, modelling studies also attempted to better understand the relative role of the particle transformation processes that set $\mathrm{J}_{100}$, such as algal size and particle transformations by the pelagic foodweb (Michaels and Silver, 1988). Subsequent globalscale models now include algal properties such as large versus small algal cells (Laws et al., 2000).

In several regions, attempts have been made to link distinct biogeochemical signatures, such as the spring bloom, in the surface and deep ocean (e.g. Asper et al., 1992; Boyd and Newton, 1995; 1999; Stemmann et al., 2000). However, assessment of the coupling between surface and deep ocean fluxes involves many uncertainties. These include temporal and spatial mismatches between datasets, due to particle sinking rates (see discussion in Boyd and Newton, 1999), and statistical funnels (of large areal extent, 10 km’s) for sinking particles (Siegel et al., 1990; Siegel and Deuser, 1997), respectively. Moreover, to assess the coupling between the surface and the subsurface ocean (the Twilight Zone, defined as the base of the euphotic zone to 1000 m (VERTIGO, 2008)) requires the interpolation of export fluxes at depth (150 m to $1000 \mathrm{~m})$ towards the surface ocean (for example, to estimate $\mathrm{J}_{100}$, see Bender et al., 1992). Such interpolation, in regions such as the NE Atlantic (Bender et al., 1992) has often used the exponent of the power law curve (i.e. the $\mathrm{b}$ value for the particle flux attenuation curve from the $\mathrm{N}$ Pacific (Martin et al., 1987)). However, it has now been established that such b values vary regionally (see review, Boyd and Trull, 2006). 
Thus, to make more robust assessment of the surface-subsurface coupling requires methodological improvements to obtain site-specific b values from the subsurface ocean, and to define the temporal and spatial relationships between surface productivity events and their subsequent 'sedimentation trajectory' through subsurface waters.

The VERTIGO program was of two years duration and one of its aims was to determine "What controls the efficiency of particle export between the surface and subsurface ocean? (VERTIGO, 2008; Buesseler et al., this volume). VERTIGO has overcome many of the issues that restricted progress in examining both the nature and degree of coupling between surface and subsurface biogeochemical processes. Specifically, it used real-time physical modelling and observations to better predict the trajectory of sinking particles, in the Twilight Zone, that originated in the mixed layer (Siegel et al., 2007). During VERTIGO, this led to specific sampling programmes for surface waters, and sampling downstream for subsurface processes. Also VERTIGO employed Neutrally Buoyant Sediment Traps (NBSTs, Valdes and Price, 2000; Stanley et al., 2003) deployed at depths between $150 \mathrm{~m}$ and $500 \mathrm{~m}$. NBSTs minimise hydrodynamic biases (Gust et al., 1996), and have enabled more robust estimates of both elemental (e.g. POC) and biological (e.g. algal pigments) sinking fluxes, and their attenuance with depth (b values, Buesseler et al., 2007) to be made in the subsurface ocean. Together, these novel approaches provide a platform necessary to better assess the nature of the surface-subsurface coupling of biogeochemical processes in the open ocean.

The present study explored the surface-subsurface coupling using both conventional and new approaches. Data on the size-partitioning of NPP, and observations on foodweb 
structure were used in conjunction a foodweb/export flux model (Michaels and Silver, 1988). This approach has been used in the past to obtain more accurate predictions' of export flux, than other methods, for a range of oceanic provinces (Boyd and Newton, 1995; 1999). Although uncertainties exist regarding the selection of trophic transfer efficiencies in such a foodweb/export model (Straile, 1997), the largest unknown in estimating export fluxes is in assigning a ratio of the proportion of NPP that is exported directly (settling as algal aggregates) versus indirectly (settling as faecal pellets). To overcome this issue, quantification of the proportion of algal versus faecal flux to $150 \mathrm{~m}$ depth was estimated by a variety of approaches - including pigment fluxes, microscopy of NBST samples and faecal pellet enumeration. Together, they provide a better estimate of the proportion of NPP exported from the base of the euphotic zone at the two VERTIGO sites.

\section{Study sites and Methods}

The two VERTIGO sites were in contrasting biogeochemical provinces - the ALOHA station in Low Nitrate Low Chlorophyll (LNLC) oligotrophic waters north of Hawaii (22 ${ }^{\circ} 45^{\prime} \mathrm{N} 158^{\circ} \mathrm{W}$, Karl et al., 2001) and the Japanese K2 time-series station in NW Pacific waters characterized by an early summer chlorophyll peak (ca. $1 \mu \mathrm{g} \mathrm{L}^{-1}$ ) and followed by High Nitrate Low Chlorophyll (HNLC) conditions $\left(47^{\circ} \mathrm{N}, 161^{\circ} \mathrm{W}\right.$, Harrison et al., 1999; Honda, 2003; Honda et al., 2006). The study in July 2004 was at ALOHA, and the K2 site was occupied in July and August 2005. Both cruises were organized around two deployments of 3-5 day duration to estimate particle fluxes using multiple NBSTs and to obtain estimates of particle properties and sources. Separated by 2-3 days, these successive occupations of ALOHA and K2 are referred to here as deployment 1 and 
2. For further details, see the overview by Buesseler et al. (this volume). Unlike many previous studies in which surface processes and subsurface particle fluxes are obtained from the same geographical location (e.g. Asper et al., 1992), during VERTIGO the sampling sites for surface water processes were located in the predicted source region for particles i.e. upstream of the array of NBSTs which were subsequently (3 days) deployed at 150, 300 and $500 \mathrm{~m}$ depth (Siegel et al., 2007). Siegel et al. (2007) derived trajectories of the sinking particles from statistical funnels based on upper ocean current velocities from shipboard ADCP and an assumed sinking rate for particles of 50 to $150 \mathrm{~m} \mathrm{~d}^{-1}$ (see Results).

Phytoplankton stocks throughout the upper water column were estimated using size-fractionated chlorophyll ( $>20 \mu \mathrm{m}, 5-20,2-5$ and $0.2-2 \mu \mathrm{m}$ porosity $47 \mathrm{~mm}$ diameter polycarbonate filters, filtered in series after Gall et al. (2001)) at both sites. Filtration was done under gravity, except for the $0.2-2 \mu \mathrm{m}$ fraction $(<80 \mathrm{~mm}$ Hg vacuum). Samples (3 pseudo-replicates at each depth) were obtained from 10L acid-washed Niskin bottles on the SeaBird CTD rosette. The physiological status of the resident phytoplankton $\left(\mathrm{F}_{\mathrm{v}} / \mathrm{F}_{\mathrm{m}}\right.$, photosynthetic competence) was assessed using a Chelsea Instruments Fast Repetition Rate Fluorometer (FRRF) in benchtop mode and with discrete samples (4 pseudoreplicates from each depth) from 6 depths within the mixed layer and Deep Chlorophyll Maximum (DCM) (ALOHA and K2) after Boyd and Abraham (2001). In all cases, a dark adaptation time of $>30$ minutes was used for discrete samples.

At the K2 site, shipboard iron-enrichment experiments (1 nM Fe, added as 1:1.5 Fe:EDTA; Boyd et al., 1996) were conducted on water from both the surface mixed layer and the DCM to establish whether low dissolved iron concentrations in the upper ocean 
were responsible for the sub-maximal $\mathrm{F}_{\mathrm{v}} / \mathrm{F}_{\mathrm{m}}$ evident in the resident phytoplankton.

During these experiments, temporal changes in both $\mathrm{F}_{\mathrm{v}} / \mathrm{F}_{\mathrm{m}}$ and chlorophyll concentrations were used to monitor the response of the cells to iron-enrichment. The FRRF was also used to determine the physiological status of ‘dregs’ (sensu Gardner, 1977), i.e. cells or biogenic particles that have sunk (within 30 minutes) below the level of the water spigot in 10 L Niskin bottles.

The size-partitioning of NPP was measured using the ${ }^{14} \mathrm{C}$ technique and simulated in situ incubations of $24 \mathrm{~h}$ duration using six light levels (50\% to 0.5\%) after Boyd and Harrison (1999), but modified to take into consideration the ${ }^{14} \mathrm{C}$ protocol used at Hawaii Ocean Time-series (HOT, Karl et al., 1996; Corno et al., 2006). The size fractions employed, number of pseudo-replicates, and the filtration procedure for each fraction are as described above for chlorophyll. Radioisotope uptake in dark bottles was subtracted from those measured in the light bottles. The activity of both radioisotope primary stocks and on filters were both determined using the same liquid scintillation cocktail and scintillation counter fluid as used for the HOT program. Water-column integrated NPP was estimated to the depth of ca. $1 \mathrm{mg} \mathrm{C} \mathrm{m}^{-3} \mathrm{~d}^{-1}$ which was around $125 \mathrm{~m}$ (i.e. base of the DCM) and between 48 and $58 \mathrm{~m}$ at ALOHA and K2, respectively. Note, the large sitespecific difference in the depth of column-integrated NPP has implications when comparing the POC export flux from the euphotic zone with that at $150 \mathrm{~m}$ depth where the shallowest NBST was deployed (see discussion in Boyd and Newton, 1999).

Quantification of the degree of the surface-subsurface biogeochemical coupling required an assessment of the fate of NPP. Thus, approaches were needed to track direct algal export to depth. At K2 only, samples - using the same size fractions employed for 
NPP - were taken for both algal pigments and epi-fluorescence microscopy. Phytoplankton pigments were analysed using HPLC following Bidigare et al. (2005). The upper ocean phytoplankton community was examined at both ALOHA and K2 sites using a combination of sample types: (A) samples drawn both from Niskin water bottles closed at discrete depths within the euphotic zone, and (B) net tow samples obtained from a 1/4 m diameter , $20 \mu \mathrm{m}$ net tow drawn vertically from $~ 15 \mathrm{~m}$ to the surface; details of the microscopy employed are presented in Appendix A. This enabled a link to be established between the size-partitioning of NPP, pigments and floristics. This subsequently was used to explore the relationship between upper ocean phytoplankton processes and the flux of algal pigments and algal cells in traps at $150 \mathrm{~m}$ depth. Also at K2 only, the size-partitioning of opal (>20 $\mu \mathrm{m}, 5-20 \mu \mathrm{m}, 0.4-5.0 \mu \mathrm{m})$ was used to examine the relationship between sources of mineral ballast and phytoplankton community structure. Samples for opal were obtained on polycarbonate filters from MULVFS pumps in the upper $150 \mathrm{~m}$ of the water column after Bishop et al. (1985).

Data from size-fractionated NPP were used as input into a foodweb and export flux model (Michaels and Silver, 1988), as applied previously by Boyd and Newton (1995; 1999). The model output represents the potential export of particles from the base of the euphotic zone. For more details on the trophic transfer efficiencies used in the model see Table 1a. As both sites were characterized by DCM's the export term represents export from the base of the euphotic zone, as opposed to the surface mixed layer. The structure of the pelagic foodweb used in model runs was selected using observations on the dominant upper ocean grazers at ALOHA/HOT and K2 (Table 1B). The ratio of how much algal carbon was exported directly or indirectly (after herbivory as 
faecal pellets) was set based on observations of different particle types (algal versus faecal aggregates, See later). As there was no significant change in algal stocks over time at either site during the VERTIGO deployments, in the model it was assumed that all NPP was either grazed with subsequent sinking of faecal material to depth, or sank directly to depth.

\section{Results}

\section{Phytoplankton stocks}

Phytoplankton stocks were assessed at two pelagic stations, 12 days apart, at ALOHA, and 8 stations sampling during deployments 1 and 2 at the K2 site. At ALOHA, community biomass was ca. $0.1 \mu \mathrm{g}$ chl $a \mathrm{~L}^{-1}$, and was dominated by picoplankton during both deployments, with cells $>20 \mu$ m contributing $<10 \%$ to algal stocks (Fig. 1). In contrast, there were marked differences between the two deployments of K2, with the first (31 July to 6 August 2005) being dominated by both picoplankton and > $20 \mu \mathrm{m}$ cells in the upper water column (total stocks $0.4 \mu \mathrm{g}$ chl $a \mathrm{~L}^{-1}$ ), with low biomass in both the 2-5 and 5-20 $\mu$ m classes (Fig. 2). There was evidence of a decrease in mixed layer chlorophyll concentrations in the $>20 \mu \mathrm{m}$ fraction between 31 July and 2 August (see Fig. 2a and 2b). A DCM was present at both ALOHA (ca. $125 \mathrm{~m}$ depth) and K2 (ca. 55 m depth) and was always dominated by picoplankton (Figs. 1-3). At K2, during the second deployment both the mixed layer and DCM were dominated by picoplankton, and the algal stocks were around $0.2 \mu \mathrm{g}$ chl $a \mathrm{~L}^{-1}$ over this period (Fig. 3).

No floristic samples, that had been size-partitioning in the same manner as for chlorophyll and NPP, were taken during the ALOHA VERTIGO study. Microscopy of 
bulk samples revealed that the assemblage was dominated by picoplankton - both Synechococcus, as evidenced by the typical yellow auto-fluorescence of the appropriately-sized cells, and also unknown red-fluorescing picoplankton-sized cells that could have been either other light-capturing prokaryotes or tiny chl $a$ containing eukaryotes. SEM preparations of the samples indicated that nanoplankton included several species of coccolithophorids, including Emiliani huxleyi. Occasional colonies or single filaments of Trichodesmium were also noted. At K2, microscopic examination of phytoplankton with each size fraction during the first station deployment 1 revealed that the $>20 \mu \mathrm{m}$ fraction was dominated by diatoms (mainly Pseudo-nitzschia and Chaetoceros spps, along with Coretheron), and with relatively few dinoflagellates (Table 2). The $<5 \mu \mathrm{m}$ fraction was mainly composed of yellow-fluorescent Synechococcus, with low abundances of autotrophic nanoflagellates. Additionally, picoplankton included very small ( $<1 \mu \mathrm{m})$ rapidly fading, deep red-fluorescing cells that were evident in preparations made at sea, and especially in digital images of the $0.2 \mu \mathrm{m}$ filter preparations. Our colleagues on the cruise later determined, via pigment analysis, that the populations included sizable populations of Bchl a-containing cells ( N. Jiao, pers. comm.), and small quantities of divinyl Chl a containing Prochloroccus (R. Bidigare, pers. comm.). Such cells were probably the very small, deep red fluorescing picoplankton. Additionally, species of silica-walled Parmales were noted in SEM preparations of the nanoplankton-size fraction of the phytoplankton.

Pigment analysis of the K2 samples revealed that the $>20 \mu \mathrm{m}$ fraction comprised fucoxanthin (diatoms), and alloxanthin (cryptophytes), whereas the 5-20 $\mu \mathrm{m}$ fraction contained fucoxanthin, 19'-hexanoyloxyfucoxanthin (haptophytes) and 19’- 
butanoyloxyfucoxanthin (pelagophytes) (Fig. 4). There was also a significant proportion of diatoms within the 5-20 $\mu$ m size fraction (Fig. 4). In the $<2 \mu \mathrm{m}$ fraction only zeaxanthin (cyanobacteria) was evident. Note, that these pigment data were from the end of deployment 1 at K2, when there a marked decrease in large cells had been observed (Fig. 2). At K2, the size-partitioning of opal (i.e. lithogenic and biogenic silica) was as follows: $>20 \mu$ m cells comprised $80 \%$ of mixed-layer opal, with $<5 \%$ in the $<5 \mu \mathrm{m}$ fraction, and $15 \%$ (calculated by difference) in the 5-20 $\mu \mathrm{m}$ fraction. There were similar trends in size partitioning of opal in all samples to $150 \mathrm{~m}$ depth (data not shown).

\section{Algal physiological status}

Cells at both ALOHA and K2 were resource-limited as evidenced by sub-optimal values of $F_{v} / F_{m}$ in all profiles of around 0.2-0.3 (Fig. 5a and b); the theoretical maximum in $\mathrm{F}_{\mathrm{v}} / \mathrm{F}_{\mathrm{m}}$ is 0.5 for cyanobacteria (Sandström et al., 2002), and 0.65 for diatoms (Kolber and Falkowski, 1993). Values of $F_{v} / F_{m}$ increased with depth and were around 0.4 in the DCM at ALOHA. In contrast, there was no increase in $\mathrm{F}_{\mathrm{v}} / \mathrm{F}_{\mathrm{m}}$ at the DCM at K2, nor was there any change in $F_{v} / F_{m}$ over time at $K 2$ even through shifts in algal community composition and stocks were evident between the two deployments (Figs. 2 and 3). Despite some spatial variability in chlorophyll (from satellite images; VERTIGO, 2008), underway mapping of the surrounding waters (over 90 nautical miles) revealed submaximal values of $F_{v} / F_{m}$ that were similar to that measured routinely at K2 (Fig. 5c). Shipboard experiments in which iron was added to surface waters at K2 (incubated at $30 \% \mathrm{I}_{0}$ ) resulted in both increases in $\mathrm{F}_{\mathrm{v}} / \mathrm{F}_{\mathrm{m}}$ and chlorophyll concentrations (Fig. 6) indicative of iron limitation of algal growth rate. However, the addition of iron to 
samples from the DCM at K2 (incubated at $<1 \% \mathrm{I}_{\mathrm{o}}$ ) resulted in no change in either of these properties (data not shown).

Dreg samples (of sinking particles below the level of water sampler spigots) from depths of 50 to $90 \mathrm{~m}$ at K2 (i.e. up to $40 \mathrm{~m}$ below the depth of the seasonal mixed layer) revealed that $\mathrm{F}_{\mathrm{v}} / \mathrm{F}_{\mathrm{m}}$ in biogenic particles was comparable to those in surface waters, and therefore that cells remained viable (Fig. 5d). However, at depths greater than $90 \mathrm{~m}$ there was a marked decrease in $\mathrm{F}_{\mathrm{v}} / \mathrm{F}_{\mathrm{m}}$ to low levels suggesting that cells were no longer viable. Such viable cells usually have relatively slow sinking rates $\left(<10 \mathrm{~m} \mathrm{~d}^{-1}\right.$ Waite and Nodder, 2001) relative to heterogeneous particles at K2 which exhibited a wide range of sinking rate - with half of the particle populations sinking at rates of $>100 \mathrm{~m} \mathrm{~d}^{-1}$ (Trull et al., this volume).

\section{Primary production}

At ALOHA, column-integrated NPP was similar during both stations with rates of 180+15 and 220+18 $\mathrm{mg} \mathrm{C} \mathrm{m}^{-2} \mathrm{~d}^{-1}$ (Fig. 7). On both occasions the size-partitioning of NPP was dominated by picoplankton (66-90\%; Fig. 7), with the relatively rare cells $>20$ $\mu \mathrm{m}$ contributing $9 \%$ of column-integrated NPP. The DCM made a relatively small contribution to column-integrated NPP. At K2, as noted for algal stocks and community composition, there were pronounced differences in NPP between the two deployments. The first deployment was characterised by rates of $450 \pm 37$ to $603+49 \mathrm{mg} \mathrm{C} \mathrm{m}^{-2} \mathrm{~d}^{-1}$, and NPP was dominated by cells $<2 \mu \mathrm{m}(>40 \%$ ) and $>20 \mu \mathrm{m}$ (30\%) (Fig. 8). The DCM was relatively unproductive at this station during either deployment (Figs. 8 and 9). During the second deployment, NPP rates were lower, and ranged from $302 \pm 34$ to $478+44 \mathrm{mg} \mathrm{C}$ 
$\mathrm{m}^{-2} \mathrm{~d}^{-1}$ (Fig. 9), with picoplankton contributing > 55\%, and with increases in NPP over time being due to picoplankton. Throughout this period, NPP by cells $>20 \mu \mathrm{m}$ was constant at 50-70 $\mathrm{mg} \mathrm{C} \mathrm{m}^{-2} \mathrm{~d}^{-1}$ (Fig. 9).

\section{Modelling particle production}

A foodweb modelling approach was used to explore the cumulative effects of observed changes in both NPP and algal size structure on downward POC export out of the euphotic zone (Fig. 10). A foodweb scenario, that matched published observations from both ALOHA (and HOT) and K2, was selected to derive the predicted export flux from the base of the euphotic zone (Table 1b). In this scenario, the basic foodweb of Michael and Silver (1998) was employed, with one modification. Bacterial production and NPP associated with pico- and nano-plankton passed through the microbial/metazoan foodweb. However, based on a wide range of observations by other groups within VERTIGO (Table 3, see Discussion), the NPP associated with the micro-plankton was partitioned between direct algal sinking ( 0.2 at ALOHA; 0.1 at K2) and grazing by mesozooplankton (0.8 (ALOHA) and $0.9(\mathrm{~K} 2))$. Using this approach we obtained euphotic zone export fluxes of 20-22 $\mathrm{mg} \mathrm{C} \mathrm{m}^{-2} \mathrm{~d}^{-1}$ for the two stations at ALOHA (Fig. 10a and b). This export represents $10-11 \%$ of column-integrated NPP at this oligotrophic site. At K2, for deployment 1 we predict export fluxes of $111 \mathrm{mg} \mathrm{C} \mathrm{m}^{-2} \mathrm{~d}^{-1}$ for 31 July 2005 (Fig. 10c), with a range of 78-111 $\mathrm{mg} \mathrm{C} \mathrm{m}^{-2} \mathrm{~d}^{-1}$ for the 4 NPP profiles (31 July to 6 August, Appendix B). These represent 15-21\% of column-integrated NPP at this HNLC site. In contrast, during deployment 2 of K2, we predict significantly reduced export 
fluxes of $33 \mathrm{mg} \mathrm{C} \mathrm{m}^{-2} \mathrm{~d}^{-1}$ for 11 August 2005 (Fig. 10d), with a range of 27-33 mg C m${ }^{-2}$ $\mathrm{d}^{-1}$ for the 4 NPP profiles between 11 and 17 August (Appendix B).

\section{Discussion}

Temporal context of VERTIGO datasets: comparison with other studies

Both of the VERTIGO locales are well-established oceanographic time-series sites, ALOHA is in the vicinity of the oligotrophic HOT site which has been sampled monthly for over a decade (Karl and Lukas, 1996), and at K2 a mooring site has been maintained since 2001 (Honda et al., 2006; Honda and Watanabe, 2007). The trends in our dataset from ALOHA support those reported for HOT - with low and relatively constant phytoplankton stocks and rates of NPP (Karl et al., 1996; Letelier et al., 1998), sub-optimal values of $\mathrm{F}_{\mathrm{v}} / \mathrm{F}_{\mathrm{m}}$ (due to $\mathrm{N}$ limitation) (Corno et al., accepted) and a community dominated by picophytoplankton with relatively few large diatoms (Letelier et al., 1993; Campbell et al., 1994; Scharek et al., 1999). However, although the chlorophyll concentrations at ALOHA during VERTIGO were comparable to those reported at HOT, rates of column-integrated NPP during the VERTIGO study were $>1.5$ lower that commonly reported at HOT (i.e. $400 \mathrm{mg} \mathrm{C} \mathrm{m}^{-2} \mathrm{~d}^{-1}$, Karl et al., 1996; Corno et al., 2006). Note, application of NPP estimates from such in situ incubations would result in around 1.5-fold higher export ratios (export from base of the euphotic zone $\left(E_{z}\right)$ /export measured at 150 m depth $\left(E_{150}\right)$ ) resulting in higher b values $(>2)$ (see Discussion).

All VERTIGO samples and standards were run on the same scintillation counter and using identical quench curves as the HOT programme, hence we can rule out this potential explanation, which has previously resulted in wide variations in NPP rates 
during ${ }^{14} \mathrm{C}$ methodological intercomparisons (Richardson, 1991), as the reason for the differing NPP rates. Therefore, the most likely explanation for these different rates in NPP is that in VERTIGO a simulated in situ incubation technique (6 light levels, 0-125 m) was used, whereas in situ incubations (6-8 depths, 5-175 m) are used routinely at HOT (Corno et al., 2006). Significant disparities, for example due to mismatches in light climate between in situ and deckboard incubations, between these two different approaches have been reported (Smith Jr. et al., 2000). Moreover, a comparison of rates of NPP rates from concurrent in situ and deckboard incubations at the HOT site revealed that rates from the former ( $\mathrm{n}=9$ incubations) were consistently greater than those using the deckboard approach (Letelier et al., 1996).

The K2 site is characterised by more seasonality, compared to ALOHA, in both chlorophyll concentration and NPP rates. Measured surface chlorophyll concentrations during VERTIGO are comparable to those derived from 8-d SeaWiFS chlorophyll composites for July and August 2005 (0.2-0.3 $\mu \mathrm{g}$ chl $a \mathrm{~L}^{-1}$; M. Honda unpublished data; Buesseler et al., this volume). In contrast, ${ }^{14} \mathrm{C}$ based column-integrated NPP rates are generally higher (Figs. 8 and 9) than those estimated using bio-optical approaches (i.e. based upon $\left.\mathrm{Ed}_{555} / \mathrm{Ed}_{443}\right)$ for K2 in July and August (150 - $400 \mathrm{mg} \mathrm{C} \mathrm{m}^{-2} \mathrm{~d}^{-1}$; seasonal average $297 \pm 99 \mathrm{mg} \mathrm{C} \mathrm{m}^{-2} \mathrm{~d}^{-1}$; Honda et al., 2006). Other studies have reported an annual range of NPP for the Western Subarctic Gyre (WSG) of 300-1000 $\mathrm{mg} \mathrm{C} \mathrm{m}^{-2} \mathrm{~d}^{-1}$ for August in 1998-2000 (Saino et al., 2002) reflecting the widespread spatial variability in phytoplankton processes across this region. Harrison et al. (1999) report an annual range for the WSG of 225-1198 $\mathrm{mg} \mathrm{C} \mathrm{m}^{-2} \mathrm{~d}^{-1}$ reflecting the spring phytoplankton productivity maximum in this region, followed by a return to HNLC conditions. During VERTIGO at 
K2, Elskens et al. (this volume) reported ${ }^{13} \mathrm{C}$ based rates of NPP, of $523 \mathrm{mg} \mathrm{C} \mathrm{m}^{-2} \mathrm{~d}^{-1}$ (deployment 1) to $404 \mathrm{mg} \mathrm{C} \mathrm{m}^{-2} \mathrm{~d}^{-1}$ (deployment 2), that were comparable to those determined using the ${ }^{14} \mathrm{C}$ technique (Figs. 8 and 9).

Tracking the fate of photosynthetically fixed carbon

Studies investigating the nature of the link between the magnitude of NPP and the consequent export flux have in general focused on either a direct or indirect connection. An example of a direct connection is the study of Pace et al. (1987) who obtained an export ratio using the NPP to export flux relationship. An indirect link is where NPP is first scaled to algal community structure, and/or foodweb structure, then related to export flux, (see Boyd and Newton, 1999). Export ratios, although widely used in global export flux models (see review, Boyd and Trull, 2006), have a > tenfold range across oceanic provinces (Buesseler, 1998). Foodweb/export models have provided insights and partial explanations for this broad range of ratio’s, such as between different biogeochemical provinces (Boyd and Newton, 1999) or temporally - for example, interannual variability in the NE Atlantic spring bloom export signal (Boyd and Newton, 1995). Recent advances in this field suggest that additional factors will impact the nature of this surfacesubsurface coupling, and include mineral ballast (Armstrong et al., 20002; Hedges et al., 2001; Passow 2004), algal physiology and sinking rates (Waite and Nodder, 2001), and a re-evaluation of the role of small phytoplankton in export (Silver and Gowing, 1991) based on recent foodweb modeling studies (Richardson and Jackson, 2007).

Algal markers, such as pigments and key species, provide a means to track (semiquantitatively) the fate of surface NPP. The study by Scharek et al. (1999), at the HOT 
site, is one of only a few which have attempted to track the fate of large cells (diatoms) from the base of the euphotic zone to depths $>2 \mathrm{~km}$, - using diatom abundances for difference species throughout the water column. During VERTIGO, the fate of algal carbon was tracked by linking the size-partitioning of NPP with concurrent information on the main algal species and key pigments in each size class. Microscopic enumeration and/or quantification of pigment concentrations in sub-samples taken from the NBSTs and other sediment traps fluxes then provide an important link between these strands of information. Observations on the extent and nature of particle transformations were available during VERTIGO from several sources - mesozooplankton grazing, analysis of mesozooplankton faecal pellets, and identification of the dominant particle types (i.e. aggregates versus single cells/animals, faecal versus algal aggregates) within sediment traps loaded with polyacrylamide gels (Table 3). Together such information informed the selection of the most apt version of the foodweb / particle flux model (Tables 1 and 3).

During VERTIGO, upper ocean profiles of Thorium disequilibria indicate that the main zone of particle production was within the seasonal mixed layer (there was also some evidence of particles losses down to the DCM at both sites), and particle remineralisation immediately below the DCM at K2 (60 m depth, mixed layer depth 49$54 \mathrm{~m}$ ) and ALOHA (130 m depth; mixed layer depth 26-31 m) (Pike et al., 2006). The upper ocean was where the highest rates of NPP (i.e. particle production, Figs. 7-9), mesozooplankton stocks and heterotrophic bacterial activity (i.e. particle destruction) were observed (Steinberg et al., in press). Moreover, at K2 indirect estimates of grazing by mesozooplankton point to low rates of herbivory on mixed-layer phytoplankton (14$20 \%$ of NPP, Kobari et al., this volume) with mesozooplankton mainly grazing large 
phytoplankton (> $20 \mu \mathrm{m}$ NPP was 12->30\% of total NPP, Figs. 8 and 9) , yet chlorophyll concentrations remained constant. This strongly suggests that microzooplankton were both the main herbivores, and an important prey source for copepods, consistent with the structure used in the standard foodweb/export model (Table 1).

The predictions from the foodweb model, resulted in a ca. three-fold range of export fluxes for K2, but a negligible range for ALOHA (Fig. 10). At K2, data from microscopy, algal pigments, faecal pellet analysis processes and observations of particle characteristics using polyacrylamide gels all suggest that faecal rather than algal aggregates were dominant between $60 \mathrm{~m}$ and $150 \mathrm{~m}$ depth (Table 3). Interestingly, the algal aggregates were mainly diatom-based at K2, but dominated by small cells (such as cyanobacteria) at ALOHA (Lamborg et al., this volume). The reasons behind these trends are beyond the scope of the present study, but are being further investigated using a range of modelling simulations (Richardson et al., in prep.).

There are differences in the ratio of algal to faecal-mediated export, at both the K2 and ALOHA sites, due to the range of methodological approaches used (Table 3). Microscopic observations of polyacrylamide gels from K2 reveal that 80-90\% of intercepted particles at $150 \mathrm{~m}$ depth were faecal aggregates (Trull et al., this volume), fourfold higher than estimated by Wilson et al. (this volume) from analysis of individual faecal pellets (i.e. amorphous faecal aggregates were excluded from this enumeration) from NBSTs (see Table 3). Data on algal export flux support the observations of Trull et al. (this volume). The flux of intact diatoms (derived from fucoxanthin) intercepted by the NBST at $150 \mathrm{~m}$ (Lamborg et al., this volume), was a small proportion of the mixedlayer fucoxanthin inventory (Table 3), and was relatively insignificant compared to the 
POC export flux (Buesseler et al., this volume). Microscopic enumeration of diatoms intercepted by the $150 \mathrm{~m}$ trap also revealed relatively few intact cells at both ALOHA and K2 (M. W. Silver, unpublished data). Some of this subsurface population probably remained viable (Fig. 5d) for several days (see Berges and Falkowski, 1998) prior to sinking to depths.

The majority of observations in Table 3 suggest that the ratio of large phytoplankton cells that sank directly versus indirectly (i.e. faecal pellets), from the base of the euphotic zone, was around 0.1:0.9 at K2, but slightly higher at ALOHA (0.2:0.8). Applying this ratio to the model, to define the fate of algal cells $>20 \mu \mathrm{m}$, yields predicted export fluxes of 20-22 mg POC $\mathrm{m}^{-2} \mathrm{~d}^{-1}$ at ALOHA (i.e. $>10 \%$ of column integrated NPP), and at K2 (deployment 1) 111 mg POC m${ }^{-2} \mathrm{~d}^{-1}$ (i.e. 15-21 \% of column integrated NPP during deployment 1 (Appendix B)) followed by a significantly reduced export flux of 33 mg C m${ }^{-2} \mathrm{~d}^{-1}$ (i.e. (8-9\% of column integrated NPP during deployment 2 (Appendix B)). These give export ratios ( $E_{z} / E_{150}$ of 1.3 (ALOHA (125 m depth), K2 deployment 1 (55 m depth)) and 1.2 (K2 deployment 2, $60 \mathrm{~m}$ depth). This suggests that after initial particle transformations in the euphotic zone, there is $10-20 \%$ attenuation of the particle export flux between 125 and 150 m depth at ALOHA (i.e. equivalent to a b value of 1.2). In contrast at K2 there is $20-25 \%$ attenuation of the export signal between ca. $60 \mathrm{~m}$ and 150 m depth - i.e. lower b values ( 0.55 for deployment $1 ; 0.41$ for deployment 2$)$ at K2 relative to ALOHA. This is consistent with reports of lower b values at K2 (0.4-0.5) relative to ALOHA (1.2-1.3) for the particle export flux between 150 and $500 \mathrm{~m}$ depth (see Appendix for $\mathrm{E}_{500}$ data) as estimated from NBSTs during VERTIGO (Buesseler et al., 2007). 
Relative role of surface versus subsurface processes in setting export flux

One of the central questions addressed by VERTIGO was to what extent particle processes in the upper ocean, versus those in the subsurface ocean, controlled export fluxes (VERTIGO, 2008). A recent review of datasets from the JGOFS programme indicate that both the surface (i.e. $\mathrm{E}_{\mathrm{ez}}, 2-20 \%$ NPP exported) and deep ocean (i.e. $1000 \mathrm{~m}$ and deeper, 6-25\% of $\mathrm{E}_{\mathrm{ez}}$ exported) ocean contribute equally to setting the attenuation of the NPP signal (Boyd and Trull, 2006). However, this conclusion is based on a comparison of observations from disparate sources, including NPP, export ratios, ThE ratio’s in the upper ocean, and many deep-moored trap observations (Boyd and Trull, 2006). VERTIGO provided an opportunity to compare the attenuation of the NPP signal at two depth horizons, the upper ocean (to the base of the euphotic zone), and the 150 500 m stratum within the Twilight Zone.

There was a four-fold range of export fluxes at $150 \mathrm{~m}$ depth observed during VERTIGO between ALOHA and K2, and a threefold range between the two site deployments at K2 (Buesseler et al., 2007). Such a wide range of export fluxes provides an opportunity to explore whether the surface horizon was more influential than the subsurface horizon in setting export flux. If this was so, the attenuation of NPP in the upper ocean should exceed the attenuation of $E_{\mathrm{ez}}$ to $500 \mathrm{~m}$ depth. At ALOHA, 10-11\% NPP exited the euphotic zone, whereas at K2, 16-21\% (deployment 1) and 8-11\% NPP (deployment 2) settled below this light depth (i.e. $\mathrm{E}_{\mathrm{ez}}$ ). The export flux from the surface ocean was attenuated such that $16 \%$ of $\mathrm{E}_{\mathrm{ez}}$ sank beyond $500 \mathrm{~m}$ depth at ALOHA, suggesting that the surface and subsurface ocean have comparable influence of the 
attenuation of NPP at this site. In contrast, at K2 33\% (deployment 1) and 48\% (deployment 2) of $\mathrm{E}_{\mathrm{ez}}$ sank beyond $500 \mathrm{~m}$ depth, suggesting that the surface ocean had a greater impact on the attenuance of NPP.

At K2 there was a marked difference between export fluxes (150 m to $500 \mathrm{~m}$ ) during deployment 1 and 2, yet this appeared to have no impact on the attenuance of particle flux with similar b values for each deployment period (Buesseler et al., 2007). Similarly, the b values estimated for $\mathrm{E}_{150} / \mathrm{E}_{\mathrm{ez}}$ showed little change between deployments, and were comparable to those computed by Buesseler et al. (2007) for $E_{500} / E_{150}$ (Appendix B) Thus, attenuation of particle export at K2, from $60 \mathrm{~m}$ to $500 \mathrm{~m}$ depth, does not scale to NPP, or $\mathrm{E}_{\mathrm{ez}}$, but remains invariant. However, the magnitude of $\mathrm{E}_{150}$ does reflect changes in the predicted $\mathrm{E}_{\mathrm{ez}}$. The decrease in $\mathrm{E}_{\mathrm{ez}}$ was mainly driven by combination of a decrease in column-integrated NPP and a floristic shift (which was driven by either bottom-up and/or top down controls) towards small cells. This was probably responsible for a fourfold and threefold decrease, between deployments 1 and 2, in fucoxanthin and chlorophyll export fluxes at $150 \mathrm{~m}$, respectively (Lamborg et al., this volume). Marked decreases in biogenic silica flux were also recorded between deployments 1 and 2 at K2 (Lamborg et al., this volume), consistent a decrease in the abundance of cells $>20 \mu$ m between deployments 1 and 2; 80\% of the opal was associated with the $>20 \mu \mathrm{m}$ class in surface waters.

In order to reconcile the invariance in b values between deployment 1 and 2 at $\mathrm{K} 2$, with large changes in export flux for both $\mathrm{E}_{\mathrm{ez}}$ (predicted) and $\mathrm{E}_{150}$ (observed), requires that most of the water column particle transformations take place within the upper ocean, such that the sinking material is similar in composition and physical 
properties (size, geometry) i.e. faecal pellets (see Wilson et al., this volume). Thus, particle attenuance should not alter as the same processes are acting on particle source material (phytoplankton) in the upper ocean. Therefore, the observed changes in NPP and floristic shifts will not alter the b value since the same vector (grazing by neocalanoid copepods which are present in surface waters due to their ontogenetic migration (Kobari et al., this volume)) is producing faecal aggregates. This explanation is made more compelling by i) low algal compared faecal aggregate abundances (Table 2), and ii) no change in b values between $60-150 \mathrm{~m}$ and 150 to $500 \mathrm{~m}$ between deployments.

\section{Reasons for temporal shift in phytoplankton processes at K2}

If surface processes are more important in setting export flux than subsurface processes at K2, then what mechanism(s) is controlling phytoplankton processes (NPP, community composition) in this region? The K2 site is characterized by a late spring maximum in chlorophyll concentrations, NPP and $\mathrm{E}_{150}$ that may coincide with the annual maximum in surface irradiance (Honda et al., 2006), and the WSG in general has higher mean rates of NPP and algal stocks than the NE subarctic Pacific (Harrison et al., 1999). This is probably due to its proximity to dust source regions such as the Gobi desert, and hence higher dust inputs into this region (Harrison et al., 1999), however lateral iron inputs may also be important in the NW Pacific (Nishioka et al., 2007; Lam and Bishop, in review). Although there are no dissolved iron data available for station K2, mixed layer concentrations at the nearest available site $\left(50^{\circ} \mathrm{N}, 167^{\circ} \mathrm{E}\right)$ in May 2002 (i.e. prior to the main bloom event - see Honda et al. (2006)) were 0.23 nmol Fe $\mathrm{L}^{-1}$ i.e. non-limiting to phytoplankton growth in the subarctic Pacific (Kudo et al., 2006). However, following 
the late spring (June) productivity maximum at K2, algal stocks and NPP are relatively constant over the remainder of the growth season (Honda et al., 2006), even though macronutrient concentrations remain high (Harrison et al., 1999) indicative of a shift from iron-replete to iron-deplete conditions. Shipboard observations and a perturbation experiment at K2 during VERTIGO exhibit suboptimal values of $F_{v} / F_{m}$, consistent with algal iron stress in waters with high concentrations of macronutrients, as demonstrated by iron enrichment experiments at K2 (Fig. 5). This is consistent with other shipboard and in situ iron enrichments conducted in the WSG (Harrison et al., 1999; Takeda, 1998; Tsuda et al., 2003).

The higher rates of column-integrated NPP and greater proportion of diatoms observed during deployment 1 at $\mathrm{K} 2$ are consistent with either the seasonal decline in phytoplankton processes after the June maximum, or a transient and minor alleviation of algal iron stress prior to our site deployment. Bio-optical data on the seasonal cycle of NPP at K2 in 2005 reveal a marked increase in NPP in June, followed by a rapid decrease to ambient summer NPP values by mid July (Honda et al., 2006), i.e. several weeks prior to our deployment of the K2 site for deployment 1 . Thus, a transient event, is the more likely explanation for the observed floristic shift. Such transient events (characterized by more diatoms, slightly higher algal stocks and higher NPP rates) have been reported in the HNLC waters of the NE Pacific (Boyd and Harrison, 1999). Bishop et al. (2003) have also used robotic observations to capture such a transient event, with a threefold increase in upper ocean POC, following a dust event in the NE Pacific. The observations from VERTIGO at K2 are indicative that even minor perturbations of a phytoplankton 
community (at K2, such as an iron-mediated change in both community structure and carbon fixation) may alter the POC export flux at depth.

\section{Conclusions}

i) In the NW subarctic Pacific, decreases in NPP and a floristic shift to small phytoplankton cells together result in a two- to three-fold decrease in the predicted export flux at the base of the euphotic zone $\left(\mathrm{E}_{\mathrm{ez}}\right)$. Such differences in phytoplankton processes between deployments 1 and 2 provide a useful test of the relative role of the surface and subsurface ocean on setting export fluxes, attenuance of particle export (i.e. b values). These trends in $\mathrm{E}_{\mathrm{ez}}$ at $\mathrm{K} 2$ are consistent with those observed in NBSTs deployed at three depths between 150-500 $\mathrm{m}$ at K2, and point to control of the magnitude of export fluxes by surface processes at this site.

ii) At K2, the attenuation of export flux (expressed as b values) from the base of the euphotic zone to $150 \mathrm{~m}$ (depth of shallowest NBST deployment) were comparable to those b values derived between $150 \mathrm{~m}$ and $500 \mathrm{~m}$ depth. Moreover, there was no difference in the b values between deployment 1 and 2, whereas export flux decreased by threefold. This suggests that the repackaging of particles in the surface ocean (observations suggest an algal:faecal flux ratio of 0.1 ; the algal flux was diatom-dominated) is significant in setting the degree of particle flux attenuation in subsurface waters (i.e. greater than $60 \mathrm{~m}$ depth). Such upper ocean particle transformations are also consistent with the observed lack of change in particle flux attenuance with depth despite variations in export flux.

iii) There were differences between ALOHA and K2 in the relative role of the upper versus the subsurface ocean in attenuating NPP. At ALOHA, both depth horizons have a comparable influence of the attenuation of NPP, whereas at K2 the surface ocean had a greater impact on the attenuance of NPP. 
iv) At both sites the ratio of algal:faecal export flux was estimated to be low (i.e. 0.1-0.2). At K2, this algal flux was dominated by diatoms, but at ALOHA it was mainly due to picophytoplankton.

v) The changes in both NPP and floristic shifts at K2 are consistent with the impact of episodic Fe supply to these HNLC waters. They demonstrate that even transient changes in phytoplankton processes appear to have a marked cumulative (NPP and floristics) effect on the magnitude of export fluxes to the subsurface ocean.

\section{Acknowledgments}

We thank Ken Buesseler for his vision and efforts in successfully steering the VERTIGO programme, and all of the participants in VERTIGO for providing such a stimulating and enjoyable environment. Ben van Mooy kindly provided unpublished data on heterotrophic bacterial production for use in the foodweb/export model. We are grateful to Stephanie Christiansen, who carried out analysis on the HPLC pigments, Carolyn Walker, who assisted with field sampling on the K2 voyage, Professor N. Jiao for a personal communication, Todd Wood, who was key to the success of the MULVFS program at sea, and Evelyn Armstrong, who helped with the preparation of this manuscript. We are grateful to the officers and crew of the research vessels Roger Revelle and Kilo Moana for their expertise and hospitality at sea. We acknowledge the on-shore support of scientists at both the School of Ocean and Earth Sciences, University of Hawaii (Tom Gregory, Dave Karl, Brian Popp), and at the Tohoku National Fisheries Research Institute, Fisheries Research Agency, Shinhama (Hiroaki Saito), and Japan Agency for Marine-Earth Science and Technology, Natsushima, Yokosuka, Kanagawa (Makio Honda). Funding for this research was provided by NSF (Chemical Oceanography) via a subcontract from WHOI, and by the New Zealand Public Good Science Foundation (Coasts and Oceans). MULVFS sampling (JKBB) was supported by the U.S. Department of Energy, Office of Science, Biological and Environmental Research Program under Contract No. DE-AC02-05CH11231.

\section{Tables}


Table 1 Comparison of A) Trophic Transfer Efficiencies (TTE; or gross growth efficiencies) used in the Michaels and Silver (1988) foodweb model in Fig. 10, with those from a review of experimental observations by Straile (1997); B) foodweb scenarios used by Michaels and Silver (1988) and foodweb structures reported in the literature for the two VERTIGO sites, ALOHA (references are in italics) and K2 (references in bold). Note, although the subpolar waters at K2 and the tropical ocean at ALOHA represent different environments, there was no dependency of TTE on either temperature or predator-prey weight ratio (Straile, 1997). Food concentration was the most influential factor on TTE (based on multiple regression analysis - see Fig. 3 in Straile (1997)). Thus, we have applied the same TTE for each foodweb pathway in this model.

\begin{tabular}{|c|c|c|c|c|}
\hline \multicolumn{5}{|l|}{ A) } \\
\hline \multirow{2}{*}{\multicolumn{5}{|c|}{$\begin{array}{l}\text { Observations } \\
\text { mean }\end{array}$}} \\
\hline & & & & \\
\hline Bacteria to small & 0.4 & 0.32 & $0.1-0.6$ & \\
\hline $\begin{array}{l}\text { Small Protozoan } \\
\text { to Large }\end{array}$ & 0.3 & 0.30 & $0.07-0.7$ & \\
\hline \multicolumn{5}{|l|}{ Protozoan } \\
\hline $\begin{array}{l}\text { Phytoflagellate to } \\
\text { Large Protozoan }\end{array}$ & 0.3 & 0.30 & $0.07-0.7$ & \\
\hline $\begin{array}{l}\text { Large Protozoan } \\
\text { to }\end{array}$ & 0.3 & 0.29 & $0.02-0.7$ & \\
\hline $\begin{array}{l}\text { Mesozooplanktor } \\
\text { Diatom to } \\
\text { Mesozooplanktor } \\
\text { a Michaels and Sil } \\
\text { bichaile (1997) }\end{array}$ & 0.3 & 0.29 & $0.02-0.7$ & \\
\hline \multicolumn{5}{|l|}{ B) } \\
\hline \multicolumn{5}{|l|}{ Scenario $^{\mathrm{a}}$} \\
\hline Basic & Microbial/Metazoan & Applicable & Applicable & $\begin{array}{l}\text { Campbell et al. } \\
\text { (1997); } \\
\text { Shinada et al. } \\
\text { (2001); Selph } \\
\text { et al. (2005) }\end{array}$ \\
\hline Lean & $\begin{array}{l}\text { As above but with } \\
\text { reduced TTE's }\end{array}$ & $\begin{array}{l}\text { TTE's lower } \\
\text { than mean } \\
\text { values }\end{array}$ & $\begin{array}{l}\text { TTE's lower } \\
\text { than mean } \\
\text { values }\end{array}$ & $\begin{array}{l}\text { Landry and } \\
\text { Calbet (2004); } \\
\text { Straile (1997) }\end{array}$ \\
\hline Algal & $\begin{array}{l}\text { As above but } \\
\text { permits some direct } \\
\text { algal sinking }\end{array}$ & $\begin{array}{l}\text { Applicable - } \\
\text { some direct } \\
\text { sinking }\end{array}$ & $\begin{array}{l}\text { Applicable - } \\
\text { some direct } \\
\text { sinking }\end{array}$ & $\begin{array}{l}\text { Scharek et al. } \\
\text { (1999); } \\
\text { Present Study }\end{array}$ \\
\hline Two-level & $\begin{array}{l}\text { Each grazer preys } \\
\text { on food items one } \\
\text { size smaller than in }\end{array}$ & $\begin{array}{l}\text { Insufficient } \\
\text { data available } \\
\text { to comment }\end{array}$ & $\begin{array}{l}\text { Insufficient } \\
\text { data available } \\
\text { to comment }\end{array}$ & $\begin{array}{l}\text { Shinada et al. } \\
\text { (2001) }\end{array}$ \\
\hline
\end{tabular}




$\begin{array}{lllll} & \text { Basic foodweb } & \text { further } & \text { further } & \\ \text { Generalist } & \text { Such as Salps - can } & \text { Seldom } & \text { Seldom } & \text { Huntley et al. } \\ \text { Grazer } & \text { ingest all prey sizes } & \text { reported } & \text { reported } & \text { (2006); }\end{array}$

adevised by Michaels and Silver (1988)

Shinada et al. (2001)

Table 2 The main algal species and functional groups (qualitative) at K2 for mixed-layer samples within the size classes employed for size-fractionated NPP and chlorophyll (see Figs. 2, 3, 8, 9).

\begin{tabular}{|l|l|l|l|}
\hline & & Size class & \\
\hline Station & $\mathbf{2 0} \boldsymbol{\mu m}$ & $\mathbf{5 - 2 0} \boldsymbol{\mu m}$ & $<\mathbf{m m}$ \\
\hline $\begin{array}{l}\text { K2 } \\
\text { Deployment 1 }\end{array}$ & $\begin{array}{l}\text { Pseudo-nitzschia spp., } \\
\text { Chaetoceros spp. } \\
\text { Corethron sp. } \\
\text { Coscinodiscus cf } \\
\text { marginatus. } \\
\text { Few dinoflagellates }\end{array}$ & $\begin{array}{l}\text { Gymnodinium and } \\
\text { Gyrodinium, } \\
\text { Fragilariopsis } \\
\text { present }\end{array}$ & $\begin{array}{l}\text { Synechoccocus, red- } \\
\text { fluorescing } \\
\text { prokaryotes }<1 ~ \mu m, \\
\text { some autotrophic } \\
\text { flagellates }\end{array}$ \\
\hline $\begin{array}{l}\text { K2 } \\
\text { Deployment 2 }\end{array}$ & $\begin{array}{l}\text { Aainly dinoflagellates, } \\
\text { few diatoms, mainly } \\
\text { Chaetoceros spp. }\end{array}$ & $\begin{array}{l}\text { Diverse } \\
\text { community of } \\
\text { autotrophic } \\
\text { flagellates, likely } \\
\text { including } \\
\text { coccolithophorids, } \\
\text { Parmales }\end{array}$ & $\begin{array}{l}\text { Synechoccocus, red- } \\
\text { fluorescing } \\
\text { prokaryotes }<1 ~ \mu m, ~ \\
\text { and a few } \\
\text { autotrophic } \\
\text { flagellates }\end{array}$ \\
\hline
\end{tabular}

Table 3 Estimates of the contribution of algal and faecal aggregates to export at $150 \mathrm{~m}$ depth at A) the ALOHA site during July 2004; B) the K2 site during deployments 1 and 2 
in July and August 2005. The impact of the selected ratio on predicted export flux from the base of the euphotic zone are provided in the last row of this Table.

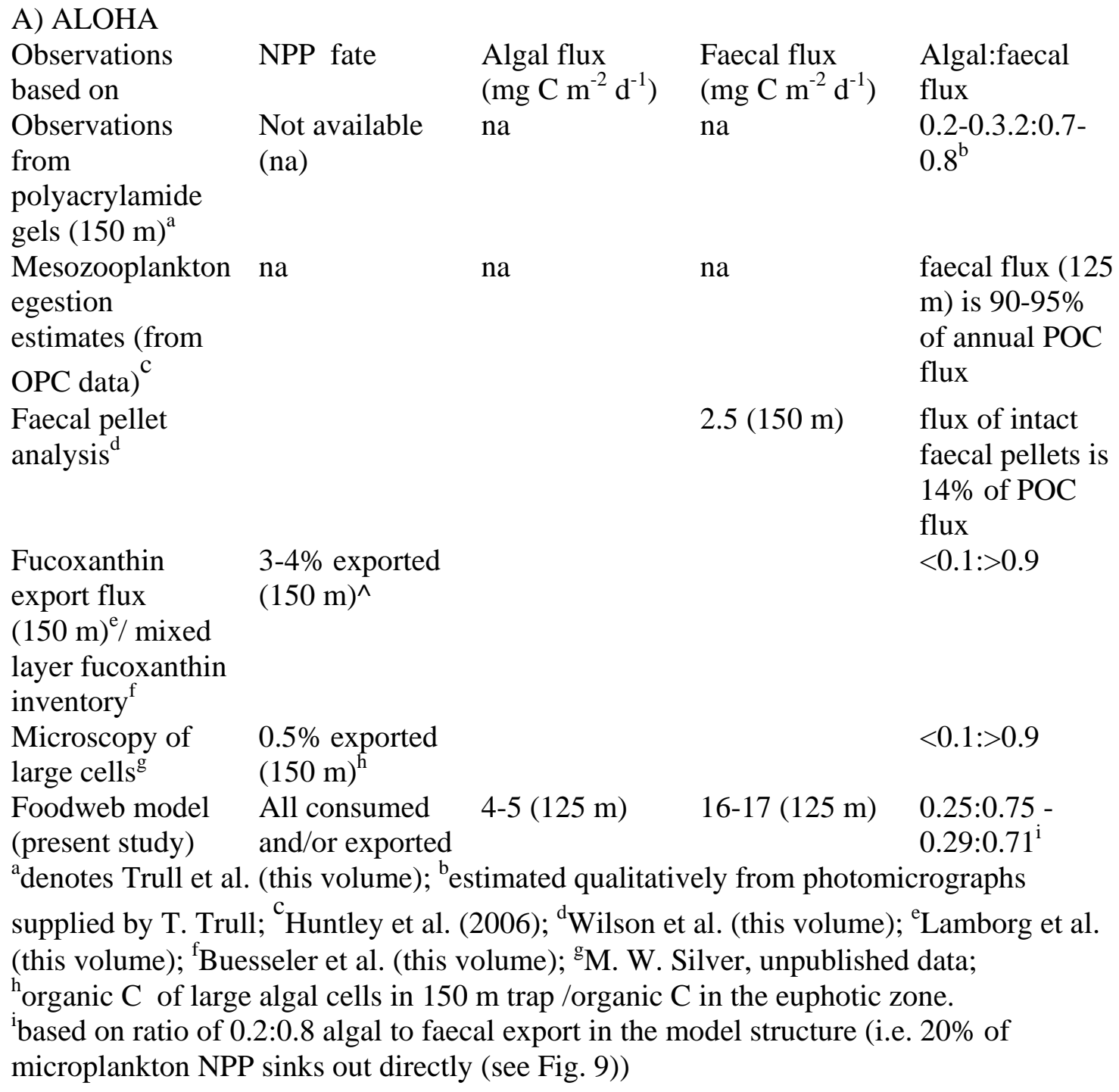

B) $\mathrm{K} 2$

\begin{tabular}{|c|c|c|c|c|}
\hline $\begin{array}{l}\text { Observations } \\
\text { based on }\end{array}$ & NPP fate & $\begin{array}{l}\text { Algal flux } \\
\left(\mathrm{mg} \mathrm{C} \mathrm{m}^{-2} \mathrm{~d}^{-1}\right)\end{array}$ & $\begin{array}{l}\text { Faecal flux } \\
\left(\mathrm{mg} \mathrm{C} \mathrm{m} \mathrm{m}^{-2} \mathrm{~d}^{-1}\right)\end{array}$ & $\begin{array}{l}\text { Algal:faecal } \\
\text { flux }\end{array}$ \\
\hline $\begin{array}{l}\text { Observations } \\
\text { from } \\
\text { polyacrylamide } \\
\text { gels }(150 \mathrm{~m})^{\mathrm{a}}\end{array}$ & na & na & na & $0.1-0.2: 0.8-0.9^{b}$ \\
\hline $\begin{array}{l}\text { Mesozooplankton } \\
\text { herbivory } \\
\text { estimates }^{j}\end{array}$ & $\begin{array}{l}14-20 \% \\
\text { grazing }\end{array}$ & & $18-27(150 \mathrm{~m})$ & $\begin{array}{l}\text { faecal flux is } \\
29-44 \% \text { of } \\
\text { POC flux }\end{array}$ \\
\hline Faecal pellet & & & $12.4(150 \mathrm{~m})$ & flux of intact \\
\hline
\end{tabular}




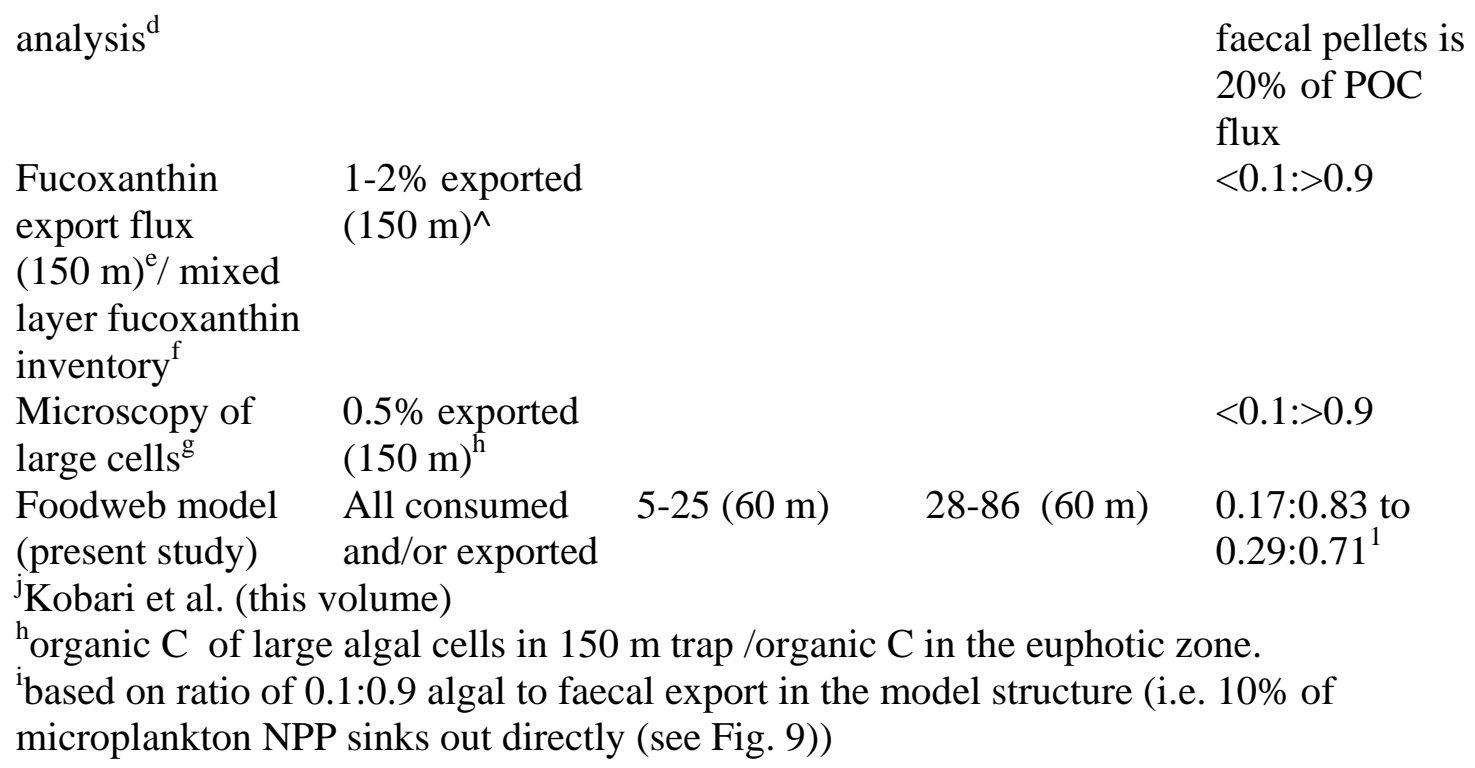

\section{Figure Legends}

Fig. 1 Vertical profiles of the partitioning of chlorophyll between 4 size classes at ALOHA A) deployment 1, 25 June 2004; B) deployment 2, 5 July 2004. The error bars represent the standard error of the mean $(n=3)$ of three pseudo-replicates from each depth. Error bars for each size class are not shown. The maximum depth of the DCM (from chlorophyll fluorescence profiles) was $135 \mathrm{~m}$ on most profiles.

Fig. 2 Vertical profiles of the partitioning of chlorophyll between 4 size classes at K2 deployment 1 for A) 31 July, B) 2 August, C) 4 August, and D) 6 August 2005 (i.e. from CTD casts 18, 23, 31, 39, respectively). Symbols and error bars are as for Fig. 1. The maximum depth of the DCM was $62 \mathrm{~m}$ (from chlorophyll fluorescence profiles) on most profiles.

Fig. 3 Vertical profiles of the partitioning of chlorophyll between 4 size classes at K2 deployment 2 for A) 11 August, B) 13 August, C) 15 August and D) 17 August 2005 (i.e. from CTD casts 62, 66, 76, 84, respectively). Symbols and error bars are as for Fig. 
1. The maximum depth of the DCM was $66 \mathrm{~m}$ (from chlorophyll fluorescence profiles) on most profiles.

Fig. 4 Partitioning of algal pigments within 4 size classes at K2 (10 m depth) on A) 5 August 2005 (CTD 39, i.e. last profile from deployment 1); B) 17 August 2005 (CTD 84, last profile of deployment 2), for the main pigment groups 19'-butanoyloxyfucoxanthin (pelagophytes), fucoxanthin (diatoms), 19'-hexanoyloxyfucoxanthin (haptophytes), alloxanthin (cryptophytes), and total chlorophyll. The other main pigment group zeaxanthin (cyanobacteria) was predominately observed in the $<2 \mu \mathrm{m}$ fraction.

Fig. 5 Typical vertical profiles of phytoplankton photosynthetic competence $\left(F_{v} / F_{m}\right)$ at $\left.A\right)$ ALOHA (deployment 1, 25 June 2004 (CTD XX)); B) K2 (deployment 1, 2 August 2005 (CTD 23)) ; C) K2 underway sampling (100 nautical miles around the central station) of surface waters ( $4 \mathrm{~m}$ depth, 10 knots) commencing $2000 \mathrm{~h}$ local time on August 8 2005; and D) denotes a vertical profile (solid line and solid symbols, CTD 34) in $F_{v} / F_{m}$ in settling particles (referred to here as 'dregs'). Open symbols denote $F_{v} / F_{m}$ in mixed-layer water samples from $20 \mathrm{~m}$ and from the DCM.

Fig. 6 Time-series from deckboard iron-enrichment experiments using water sampled from 10 m depth at K2 (2 August 2005, CTD 23) for A) $F_{v} / F_{m} ; B$ ) chlorophyll concentrations. Solid and open symbols denote the iron-enriched and control treatments, respectively.

Fig. 7 Vertical profiles of the partitioning of Net Primary Production (NPP) between 4 size classes at ALOHA A)deployment 1, 25 June 2004; B) deployment 2, 5 July 2004. The error bars represent the standard error of the mean $(n=3)$ of three pseudo-replicates from each depth. Error bars for each size class are not shown.

Fig. 8 Vertical profiles of the partitioning of NPP between 4 size classes at K2 deployment 1 for A) 31 July, B) 2 August, C) 4 August, and D) 6 August 2005 (i.e. from CTD casts 18, 23, 31, 39, respectively). Symbols and error bars are as for Fig. 6.

Fig. 9 Vertical profiles of the partitioning of NPP (NPP) between 4 size classes at K2 deployment 2: A) 11 August, B) 13 August, C) 15 August and D) 17 August 2005 (i.e. from CTD casts 62, 66, 76, 84, respectively). Symbols and error bars are as for Fig. 6.

Fig. 10 Predictions of export flux (mg C m ${ }^{-2} \mathrm{~d}^{-1}$ ), from the base of the euphotic zone, to depth using the Michaels and Silver (1988) approach for A) ALOHA, 25 June 2004; B) K2, 5 July 2004; C) K2, 31 July 2005; D) 11 August 2005. Arrows denote the foodweb pathways (for carbon deriving from column-integrated NPP and heterotrophic bacterial production). Arrows above of M, N, P and B represent NPP by micro-, nano-, picoplankton, and heterotrophic bacterial production, (courtesy of B. van Mooy, unpublished data), respectively. $\mathrm{H}, \mathrm{C}$ and Me denote, heterotrophic flagellates, heterotrophic ciliates and mesozooplankton (copepods), respectively. Fluxes within arrows between $\mathrm{H}, \mathrm{C}$ and Me represent the trophic transfer of carbon through the foodweb, the transfer efficiencies 
are based on Michaels and Silver (1988) - see Table 1A. The export flux of algal and faecal carbon in represented by the arrows to the right of the $\mathrm{M}$ and Me boxes, respectively. At ALOHA 20\% of NPP from microphytoplankton was permitted to be exported directly, and the remainder was grazed by mesozooplankton (Table 3A), whereas $10 \%$ of microplankton NPP was exported directly at K2 (Table 3B). Note this approach cannot take into account the effects of diurnal vertical migration on export out of the surface layers.

\section{REFERENCES}

Armstrong, R.A., Lee, C., Hedges, J.I., Honjo, S., Wakeham, S.G., 2002. A new, mechanistic model for organic carbon fluxes in the ocean based on the quantitative association of POC with ballast minerals. Deep-Sea Research II 49, 219-236. 
Asper, V.L., Deuser, W.G., Knauer G.A., Lohrenz S.E., 1992. Rapid coupling of sinking particle fluxes between surface and deep ocean waters. Nature 357, 670 - 672 .

Bender, M., Ducklow, H., Kiddon, J., Marra J., Martin J., 1992. The carbon balance during the 1989 spring bloom in the North Atlantic Ocean, $47^{\circ} \mathrm{N} 20^{\circ} \mathrm{W}$. Deep-Sea Research 39, 1707-1725.

Berges, J.A., Falkowski, P.G., 1998. Physiological stress and cell death in marine phytoplankton: induction of proteases in response to nitrogen- or light-limitation. Limnology and Oceanography 43, 129-135.

Bidigare, R.R., Van Heukelem, L, Trees C.C., 2005. Analysis of algal pigments by highperformance liquid chromatography. In: Algal Culturing Techniques (R. A. Andersen, Ed.), Academic Press, New York, pp. 327-345.

Bishop, J.K.B., 1989. Regional extremes in particulate matter composition and flux: effects on the chemistry of the ocean interior. In: Berger, W.H., Smetacek, V.S., Wefer, G. (Eds.), Productivity of the Ocean: Present and Past. J. Wiley and Sons, New York, pp. 117-138.

Bishop, J.K.B., Schupack, D., Sherrell, R.M., Conte, M., 1985. A multiple unit large volume in situ filtration system (MULVFS) for sampling oceanic particulate matter in mesoscale environments. In: Zirino, A. (Ed.), Mapping Strategies in Chemical Oceanography, Advances in Chemistry Series, Vol. 209. American Chemical Society, Washington, DC, pp. 155-175.

Bishop, J.K.B., Davis, R.E., Sherman, J.T., 2002. Robotic observations of dust storm enhancement of carbon biomass in the North Pacific. Science 298, 817-821.

Boyd, P.W., Newton, P., 1995. Evidence of the potential influence of planktonic community structure on the interannual variability of particulate carbon flux. Deep-Sea Research I 42, 619639.

Boyd, P.W., Muggli, D.L., Varela, D.E., Goldblatt, R.H., Chretien, R., Orians, J.K., Harrison, P.J., 1996. In vitro iron enrichment experiments in the NE subarctic Pacific. Marine Ecology Progress Series 136, 179-193.

Boyd, P.W., Newton, P., 1999. Does planktonic community structure determine downward particulate organic carbon flux in different oceanic provinces? Deep-Sea Research I 46, 63-91.

Boyd, P.W., Harrison, P.J., 1999. Phytoplankton dynamics in the NE subarctic Pacific. DeepSea Research II 46, 2405-2432.

Boyd, P.W., Abraham, E.A., 2001. Iron-mediated changes in phytoplankton photosynthetic competence during SOIREE. Deep-Sea Research II 48, 2529-2550.

Boyd, P.W., Trull, T., 2006. Understanding the export of biogenic particles in oceanic waters: is there consensus? Progress in Oceanography 72, 276-312. 
Brown, M.T., Landing, W.I., Measures, C.M., 2005. Dissolved and particulate Fe in the western and central North Pacific: Results from the 2002 IOC cruise. Geochemistry Geophysics Geosystems 6, Q10001. doi:10.1029/2004GC000893

Buesseler, K.O., 1998. The decoupling of production and particulate export in the surface ocean. Global Biogeochemical Cycles 12, 297-310.

Buesseler, K.O., Ball, L., Andrews, J.E., Cochran, J.K., Hirschberg, D.J., Bacon, M.P., Fleer, A., Brzezinski, M., 2001. Upper ocean export of particulate organic carbon and biogenic silica in the Southern Ocean along $170^{\circ} \mathrm{W}$. Deep-Sea Research II 48, 4275-4297.

Buesseler, K.O., Lamborg, C.H., Boyd, P.W., Lam, P.J., Trull, T.W., Bidigare, R.R., Bishop, J.K.B., Casciotti, K.L., Dehairs, F., Elskens, M., Honda, M.,. Karl, D.M, Siegel, D., Silver, M.W., Steinberg, D.K., Valdes, J., Van Mooy, B., Wilson, S., 2007. Revisiting carbon flux through the ocean's twilight zone. Science 316, 567-570.

Buesseler, K.O., Lamborg, C.H., Boyd, P.W., Lam, P.J., Trull, T.W., Bidigare, R.R., Bishop, J.K.B., Casciotti, K.L., Dehairs, F., Elskens, M., Honda, M., Karl, D.M., Siegel, D., Silver, M.W., Steinberg, D.K., Valdes, J., Van Mooy, B., Wilson, S., this volume. What we know from VERTIGO (VERtical Transport In the Global Ocean). Deep-Sea Research II.

Campbell, L., Nolla, H. A., Vaulot, D., 1994. The importance of Prochlorococcus to community structure in the central North Pacific Ocean (Station ALOHA). Limnology and Oceanography 39, 954-961.

Campbell, L., Liu, H., Nolla, H.A., Vaulot, D., 1997. Annual variability of phytoplankton and bacteria in the subtropical North Pacific Ocean at Station ALOHA during the 1991- 1994 ENSO event, Deep-Sea Research I 44, 167-192.

Corno, G., Letelier, R.M., Abbott, M., Karl, D., 2006. Assessing primary production variability in the North Pacific Subtropical Gyre: a comparison of fast repetition rate fluorometry and ${ }^{14} \mathrm{C}$ measurements. Journal of Phycology 42, 51-60.

Corno, G., Letelier, R.M., Abbott, M.R., Karl, D.M., in press. Temporal and vertical variability in photosynthesis in the North Pacific Subtropical Gyre. Limnology and Oceanography.

Elskens, M., Dehairs, F., Boyd, P.W., Gall, M., this volume. New, export and primary production during VERTIGO. Deep-Sea Research II.

Eppley, R.W., Reid, F.M.H., Strickland J.D.H., 1970. Estimates of phytoplankton crop size, growth rate and primary production. In: Strickland JDH (ed) The ecology of the plankton off La Jolla California in the period April through September 1967. Bullettin Scripps Institute of Oceanography, University California 17, 33-42. 
Gall, M., Strzepek, R., Maldonado, M., Boyd, P.W., 2001. Phytoplankton processes: Part 2 Rates of primary production and factors controlling algal growth during the Southern Ocean Iron RElease Experiment (SOIREE). Deep-Sea Research II 48, 2571-2590.

Gardner, W.D., 1977. Incomplete extraction of rapidly settling particles from water samplers. Limnology and Oceanography 22, 764-767.

Garrison, D.L., Gibson, A. Coale, S. L., Gowing, M. M., Okolodkov, Y., Fritzsen, C. H. and Jeffries, M. O., 2005. Sea-ice microbial communities in the Ross Sea: autumn and summer biota, Marine Ecology Progress Series 300, 39-52

Gust, G., Bowles, W., Giordano, S., Hüttel, M., 1996. Particle accumulation in a cylindrical sediment trap under laminar and turbulent steady flow: An experimental approach. Aquatic Sciences - Research Across Boundaries 58, 297-326.

Harrison, P.J., Boyd, P.W., Varela, D.E., Takeda, S., Shiomoto, A., Odate, T., 1999. Comparison of factors controlling phytoplankton productivity in the NE and NW subarctic Pacific gyres. Progress in Oceanography 43, 205-234.

Hedges, J.I., Baldock, J.A., Gélinas, Y., Lee, C., Peterson, M.L., Wakeham, S.G., 2001. Evidence for non-selective preservation of organic matter in sinking marine particles. Nature 409, 801-804.

Honda, M.C., 2003. Biological pump in the northwestern North Pacific. Journal of Oceanography 59, 671-684.

Honda, M.C., Kawakami, H., Sasaoka, K., Watanabe, S., Dickey, T., 2006. Quick transport of primary produced organic carbon to the ocean interior. Geophysical Research Letters 33, L16603. doi:101029/2006GL026466.

Honda, M.C., Watanabe, S., 2007. Utility of an automatic water sampler to observe seasonal variability in nutrients and DIC in the NW North Pacific. Journal of Oceanography 63, 349-362.

Huntley, M.E., Lopez, M.D.G., Zhou, M., Landry, M.R., 2006. Seasonal dynamics and ecosystem impact of mesozooplankton at Station ALOHA, based on OPC measurements. Journal of Geophysical Research, 111, C05S10. doi:10.1029/2005JC002892.

Karl, D.M., Christian, J.R., Dore, J.E., Hebel, D.V., Letelier, R.M., Tupas, L.M., Winn, C.D., 1996. Seasonal and interannual variability in primary production and particle flux at Station ALOHA. Deep-Sea Research II 43, 539-568.

Karl, D.M., Lukas, R., 1996. The Hawaii Ocean Time-series (HOT) program: Background, rationale and field implementation. Deep-Sea Research II 43, 129-156. 
Karl, D.M., Björkman, K.M., Dore, J.E., Fujieki, L., Hebel, D.V., Houlihan, T., Letelier, R.M., Tupas, L.M., 2001. Ecological nitrogen-to-phosphorus stoichiometry at Station ALOHA. DeepSea Research II 48, 1529-1566.

Kobari, T., Steinberg, D.K., Ueda, A., Tsuda, A., Silver, M.W., Kitamura, M., this volume. Impacts of ontogenetically migrating copepods on downward carbon flux in the western subarctic Pacific Ocean. Deep-Sea Research II.

Kolber, Z., Falkowski, P.G., 1993. Use of active fluorescence to estimate phytoplankton photosynthesis in situ. Limnology and Oceanography 38, 1646-1665.

Kudo, I., Noiri, Y., Nishioka, J., Taira, Y., Kiyosawa, H., Tsuda, A., 2006. Phytoplankton community response to Fe and temperature gradients in the NE (SERIES) and NW (SEEDS) subarctic Pacific Ocean. Deep-Sea Research II 53, 2201-2213.

Lamborg, C.H. Buesseler, K.O., Valdes, J., Bertrand, C.H., Manganini, S., Pike, S., Steinberg, D., Trull, T., Wilson, S., Bidigare, R., this volume. The Flux of Major, Minor, Trace Elements and Phytoplankton Pigments Associated with Sinking Particles in the Mesopelagic "Twilight Zone” of the Northwest and North Central Pacific Ocean. Deep-Sea Research II.

Lampitt, R.S., 1985. Evidence for the seasonal deposition of detritus for the deep-sea floor and its subsequent resuspension. Deep-Sea Research 32, 885-897.

Lampitt, R.S., Wishner, K.F., Turley, C.M., Angel, M.V., 1993. Marine snow studies in the northeast Atlantic Ocean - distribution, composition and role as a food source for migrating plankton. Marine Biology 116, 689-702.

Lam, P., Bishop, J.L.K., in review. Is Dust Iron Supply to the HNLC North Pacific Ocean Overblown? Geophysical Research Letters.

Landry, M.R., Calbet, A., 2004. Microzooplankton production in the oceans. ICES Journal of Marine Science 61, 501-507.

Laws, E.A., Falkowski, P.G., Smith, W.O.J., Ducklow, H., McCarthy, J.J., 2000. Temperature effects on export production in the open ocean. Global Biogeochemical Cycles 14, 1231-1246.

Letelier, R.M., Bidigare, R.R., Hebel, D.V., Ondrusek, M., Winn, C.D., Karl, D.M., 1993. Temporal variability of phytoplankton community structure-based on pigment analysis. Limnology and Oceanography 38, 1420-1437.

Letelier, R.M., Dore, J.E., Winn, C.D., Karl, D.M., 1996. Seasonal and interannual variations in photosynthetic carbon assimilation at Station ALOHA. Deep-Sea Research II 43, 467-490.

Martin, J.H., Knauer, G.A., Karl, D.M., Broenkow, W.W., 1987. VERTEX: carbon cycling in the north-east Pacific. Deep-Sea Research 34, 267-285. 
Michaels, A.F., Silver, M.W., 1988. Primary production, sinking fluxes and the microbial food web. Deep-Sea Research 35, 473-490.

Nishioka, J., Ono, T., Saito, H., Nakatsuka, T., Takeda, S., Yoshimura, T., Suzuki, K., Kuma, K., Nakabayashi, S., Tsumune, D., Mitsudera, H., Johnson, W. K., Tsuda, A., 2007. Iron supply to the western subarctic Pacific: importance of iron export from the Sea of Okhotsk. Journal of Geophysical Research 112, C10012. doi:10.1029/2006JC004055.

Pace, M.L., Knauer, G.A., Karl, D.M., Martin, J.H., 1987. Primary production, new production and vertical flux in the Eastern Pacific. Nature 325, 803-804.

Passow, U., 2004. Switching perspectives: Do mineral fluxes determine particulate organic carbon fluxes or vice versa? Geochemistry, Geophysics, Geosystems, 5, Q04002. doi:01029/02003GC000670.

Pike, S., Andrews, J., Trull, T., Buesseler, K., 2006. A high resolution study of particle export using Thorium-234 in the Central Pacific and NW Pacific as part of the VERTIGO project. Eos Trans. AGU, 87(36), Ocean Sci. Meet. Suppl., Abstract OS42L-01.

Richardson, K., 1991. Comparison of ${ }^{14} \mathrm{C}$ primary production determinations made by different laboratories. Marine Ecology Progress Series 72,189-201.

Richardson, T.L., Jackson, G.A., 2007. Small phytoplankton and carbon export from the surface ocean. Science 315, 838-840.

Richardson, T.L., Boyd, P.W., Jackson G.A., in preparation. Intercomparison of different foodweb-export models for two oceanographic provinces - implications for the contribution of large versus small cells to upper ocean export flux.

Saino T., Bychkov, A., Chen, C.-T.A., Harrison, P.J., 2002. The Joint Global Ocean Flux Study in the North Pacific. Deep-Sea Research 49, 5297-5301.

Saito, H., Ota, T., Suzuki, K., Nishioka, J., Tsuda, A., 2006. Role of heterotrophic dinoflagellate Gyrodinium sp. in the fate of an iron induced diatom bloom. Geophysical Research Letters 33(9), L09602. doi: 10.1029/2005GL025366.

Sandström, S., Ivanov, A.G., Park, Y.I., Öquist, G., Gustafsson, P., 2002. Iron stress responses in the Cyanobacterium Synechococcus sp. pcc7942. Physiologia Plantarum 116, 255-263.

Scharek, R., Tupas, L.M., Karl, D.M., 1999. Diatom fluxes to the deep sea in the oligotrophic North Pacific gyre at Station ALOHA. Marine Ecology Progress Series 182, 55-67.

Selph, K.E, Shacat, J., Landry, M.R., 2005. Microbial community composition and growth rates in the NW Pacific during spring 2002. Geochemistry Geophysics Geosystems 6, Q12M05, doi:10.1029/2005GC000983. 
Shinada, A., Ikeda, T., Ban, S., Tsuda, A. 2001. Seasonal dynamics of planktonic food chains in the Oyashio region, western subarctic Pacific. Journal Plankton Research 23, 1237-1247.

Siegel, D.A., Granata, T.C., Michaels, A.F., Dickey, T.D., 1990. Mesoscale eddy diffusion, particle sinking, and interpretation of sediment trap data. Journal of Geophysical Research 95, 5305-5311.

Siegel, D.A., Deuser, W.G., 1997. Trajectories of sinking particles in the Sargasso Sea: modeling of statistical funnels above deep-ocean sediment traps. Deep-Sea Research I 44, 1519-1541.

Siegel, D.A., Fields, E., Buesseler, K.O., in press. A bottom-up view of the biological pump: model source funnels above ocean sediment traps. Deep-Sea Research I.

Silver, M.W., Gowing, M.M., 1991. The "particle" flux: origins and biological components. Progress in Oceanography 26, 75-113.

Small, L.F., Fowler, S.W., Moore, S.A., La Rosa, J., 1983. Dissolved and fecal pellet carbon and nitrogen release by zooplankton in tropical waters. Deep-Sea Research 30, 1199-1220.

Smith, W.O., Marra, J., Hiscock, M.R., Barber, R.T., 2000. The seasonal cycle of phytoplankton biomass and primary productivity in the Ross Sea, Antarctica. Deep Sea Research II 47, 31193140.

Stanley, R.H.R., Buesseler, K.O., Manganini, S.J., Steinberg, D.K., Valdes, J.R., 2004. A comparison of major and minor elemental fluxes collected in neutrally buoyant and surfacetethered sediment traps. Deep-Sea Research I 51, 1387-1395.

Steinberg, D.K., Van Mooy, B.A.S., Buesseler, K.O., Boyd, P.W., Kobari, T., Karl, D.M., 2007. Microbial vs. zooplankton control of sinking particle flux in the ocean's twilight zone. In press, Limnology and Oceanography.

Straile, D., 1997. Gross growth efficiencies of protozoan and metazoan zooplankton and their dependence on food concentration, predator-prey weight ratio, and taxonomic group. Limnology and Oceanography 42, 1375-1385.

Stemmann, L., Picheral, M., Gorsky, G., 2000. Diel variation in the vertical distribution of particulate matter ('0.15 mm) in the NW Mediterranean Sea investigated with the Underwater Video Profiler. Deep-Sea Research I 47, 505-531.

Suess, E., 1980. Particulate organic carbon flux in the oceans-surface productivity and oxygen utilization. Nature 288, 260-263.

Takeda, S., 1998. Influence of iron availability on nutrient consumption ratio of diatoms in oceanic waters, Nature, 393, 774-777. 
Tsuda A. et al. 2003. A Mesoscale Iron Enrichment in the Western Subarctic Pacific Induces a Large Centric Diatom Bloom. Science 300, 958-961. DOI: 10.1126/science.1082000.

Trull, T.W., Buesseler, K., Lamborg, C., Pike, S., Moy, C., Bray, S., Ebersbach, F., Manganini, S., this volume. In-situ Particle Sinking Rates at Mesopelagic Depths from the Sub-tropical and Sub-Arctic Pacific. Deep-Sea Research II.

Valdes, J.R., Price, J.F., 2000. A neutrally buoyant, upper ocean sediment trap. Atmospheric and Oceanographic Technology 17, 62-68.

VERTIGO (2008)

http://www.whoi.edu/science/MCG/cafethorium/website/projects/vertigo.html

Volk, T., Hoffert, M.I., 1985. Ocean carbon pumps: analysis of relative strengths and efficiencies in ocean-driven atmospheric $\mathrm{CO}_{2}$ changes. In: Sundquist, E., Broecker, W.S. (Eds.), The Carbon Cycle and Atmospheric $\mathrm{CO}_{2}$ : Natural Variations Archean to Present, AGU, Washington, DC, pp. 99-110.

Waite, A.M., Nodder, S.D., 2001. The effect of in situ iron addition on the sinking rates and export flux of Southern Ocean diatoms. Deep-Sea Research II 48, 2635-2654.

Wilson, S.E., Steinberg, D.K., Buesseler, K.O., this volume. Changes in fecal pellet characteristics with depth as indicators of zooplankton repackaging of particles in the mesopelagic zone. Deep-Sea Research II.

Yu, E.-F., 1994. Variations in the particle flux of ${ }^{230} \mathrm{Th}$ and ${ }^{231} \mathrm{~Pa}$ and paleoceanographic applications of the ${ }^{231} \mathrm{~Pa} /{ }^{230} \mathrm{Th}$ ratio. PhD Thesis, Woods Hole, USA.

\section{Appendix A Methods for microscopy}

Samples were taken as follows: from the Niskin bottles, 100ml samples were drawn and then fixed with hexamine buffered formaldehyde ( $0.6 \%$ final concentration) and stored un-concentrated in glass bottles for later viewing and cell counting. Additionally, filter preps were made for epi-fluorescent counts of organisms from water samples obtained from the Niskin bottles. Aliquots were fixed with $0.5 \%$ gluteraldehyde, incubated for 1 hour and then drawn by low vacuum pressure onto 0.8 and $5 \mu \mathrm{m}$ polycarbonate membrane filters that were briefly incubated with DAPI. These filters 
were placed on glass slides between 2 drops of immersion oil, placed in a slide box, and frozen for later examination. Initial viewing of large cells in net tow contents at sea (e.g. for Trichodesmium tufts at station ALOHA) was possible using a Cole Parmer trinocular Stereo Zoom microscope with a 10x eyepiece and 10-40x zoom objective. For net tow samples, live contents were viewed and photographed at sea using an Zeiss Axioskop with a 10x objective and 20x, 40x, 63x objectives (depending on the resolution required) either under brightfield or epiflourescence lighting conditions. Such samples were generally highly fluorescent and digital images of them provided useful information for species identification and cell condition, Additionally, filters (both 0.8 and $5.0 \mu \mathrm{m}$ poresizes) with fixed cells (the quantitative preparations) were also examined briefly at sea.

Back on land (at UCSC), samples for the larger cells (cells $>20 \mu \mathrm{m}$ ) were counted using standard Utermöhl methods and enumerated and sized using an Olympus IX 70 inverted microscope, with 10x oculars and 10x, 20x or $40 \mathrm{x}$ objective, as appropriate, and viewed by fluorescence and phase contrast microscopy. Only intact cells were counted. For the smaller cells, qualitative examinations of the dominant taxa were made on the 0.8 and $5 \mu \mathrm{m}$ filters using a Zeiss Axio Imager compound microscope with epi-fluorescent attachment. The autofluorescence of chlorophyll-a and biliprotein pigments was used to identify cells as photosynthetic. DAPI staining was useful for distinguishing dinoflagellates from other taxa. Phytoplankton flux was measured at the various sites using trap contents that were available from the uppermost $(150 \mathrm{~m}$ ) trap, which was deployed below the euphotic zone. A plankton splitter was used to obtain 500ml subsamples of trap material which was preserved with $0.6 \%$ hexamine buffered formaldehyde sea and then subsequently prepared for viewing and counting back in the 
land-laboratories. Phytoplankton in the trap subsamples were sized and counted back in the laboratory as described above for the water samples. The abundance and biomass were determined using the methods of Garrison et al., 2005. Modified Strathmann equations (Eppley et al. 1970) were used to calculate cell carbon content.

Additionally, for both ALOHA and K2 samples, samples were prepared for scanning electron microscopy (SEM), in rder to check for the presence of small mineralized cells such as members of the Parmales and coccolithophorids. For such samples, we used our standard methods for preparing Niskin bottle watersamples that had been fixed and appropriately collected on filters at sea (Garrison et al., 2005). Back in the lab these were processed, viewed, and SEM micrographs obtained of the various species, using our standard methods (Garrison et al., 2005)

\section{Appendix B Changes in biogeochemical fluxes and their vertical attenuation at ALOHA and $\mathrm{K} 2$}

Rates of NPP compared with predicted export flux at the base of the euphotic zone ( $\left.\mathrm{E}_{\mathrm{ez}}\right)$, and observed export fluxes at $150 \mathrm{~m}\left(\mathrm{E}_{150}\right)$ and $500 \mathrm{~m}\left(\mathrm{E}_{500}\right)$ depth (Buesseler et al., 2007). B values (sensu Martin et al., 1987) for each ratio are presented in parentheses.

$\begin{array}{llll}\begin{array}{l}\text { Flux }\left(\mathbf{m g ~ m}^{\mathbf{2}} \mathbf{\mathbf { d } ^ { - }}\right. \\ \text { NPP }\end{array} & \text { ALOHA } & \text { K2 deployment } \mathbf{1} & \text { K2 deployment } \mathbf{2} \\ \mathrm{NPP} & 180-220 & 450-603 & 302-478 \\ \mathrm{E}_{\mathrm{ez}} & 20-22 & 78-111 & 27-33 \\ \mathrm{E}_{150} & 18 & 62 & 23 \\ \mathrm{E}_{500} & 3.6 & 29 & 13 \\ \text { Ratio } & \text { ALOHA } & \text { K2 deployment } \mathbf{1} & \mathbf{K} 2 \text { deployment } 2 \\ \mathrm{E}_{\mathrm{ez}} / \mathrm{NPP} & 0.10-0.11 & 0.16-0.21 & 0.08-0.11 \\ \mathrm{E}_{150} / \mathrm{E}_{\mathrm{ez}} & 0.82-0.90 & 0.56-0.79(0.55) & 0.69-0.85(0.41) \\ & (1.2) & & \\ \mathrm{E}_{500} / \mathrm{E}_{150} & 0.23(1.2- & 0.47(0.51) & 0.52(0.48) \\ & 1.25) & & \end{array}$




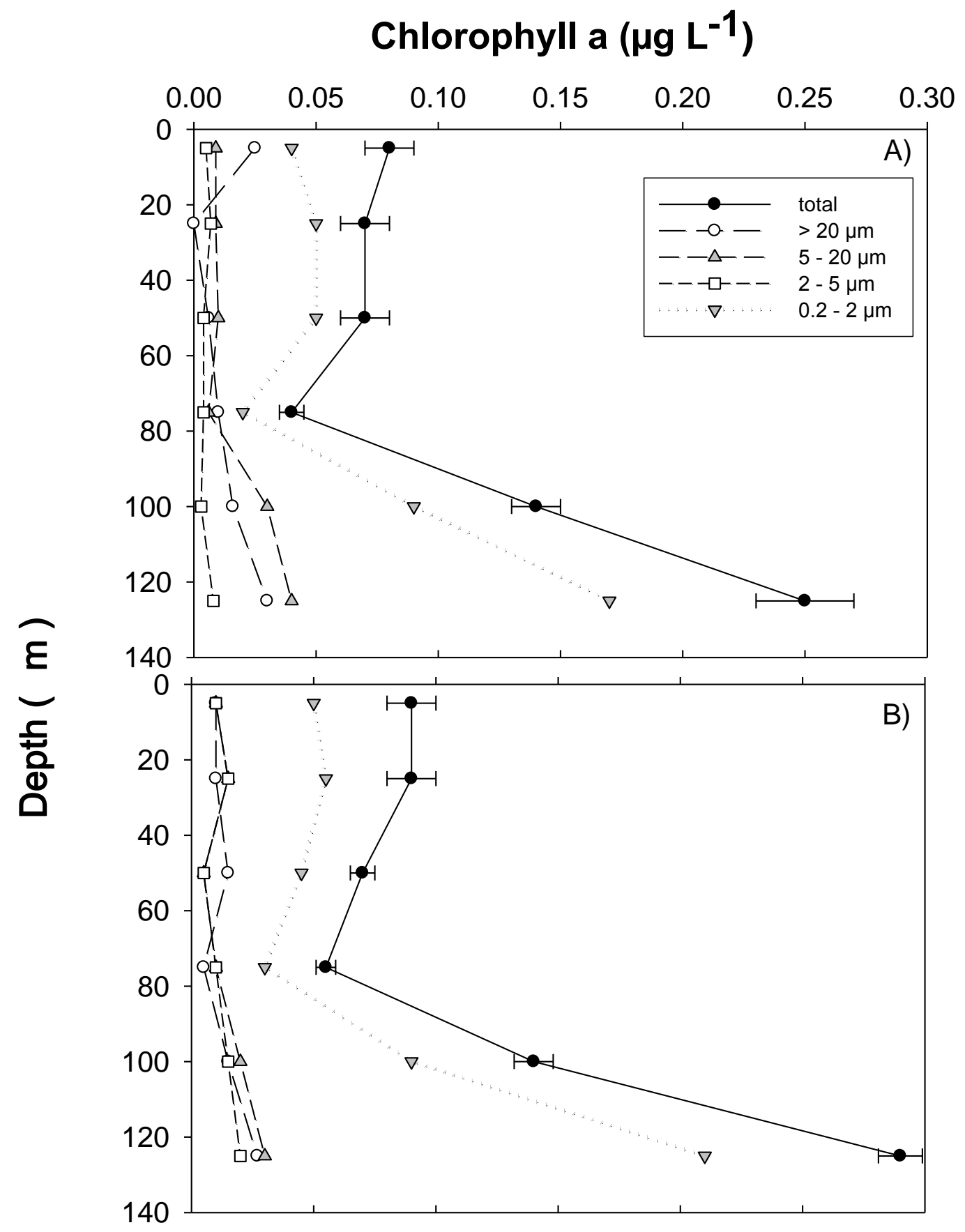




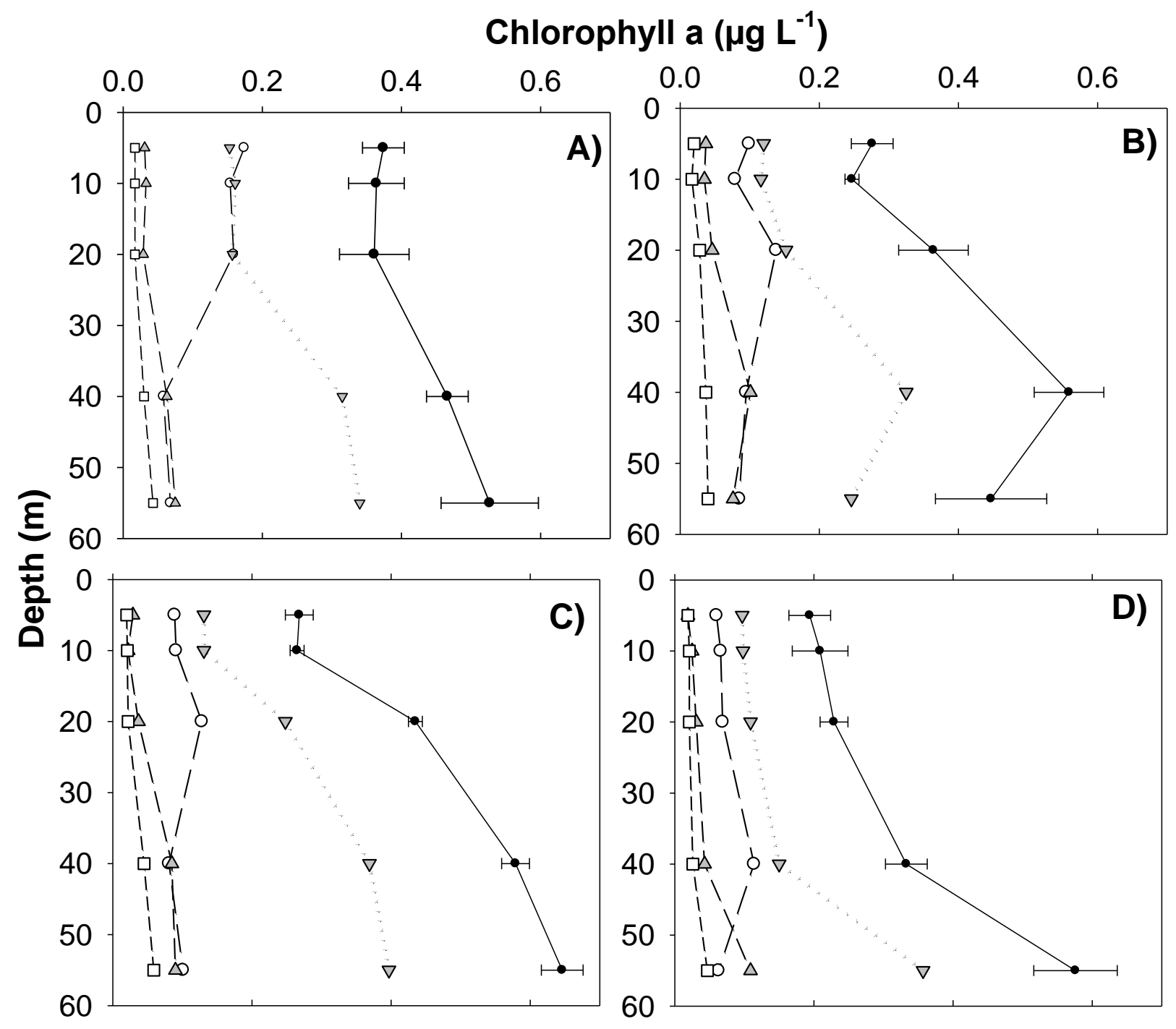




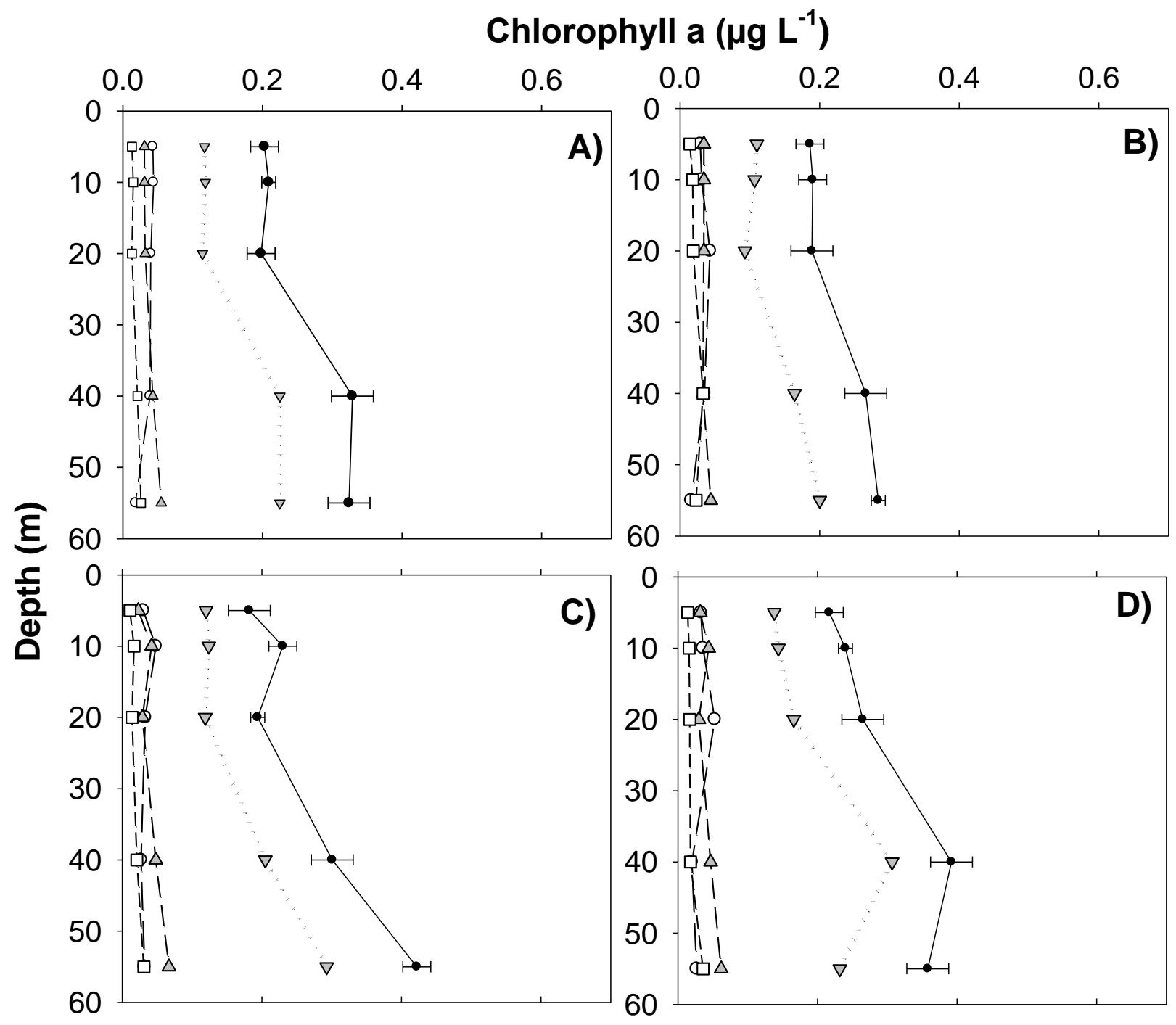


Pelagophytes
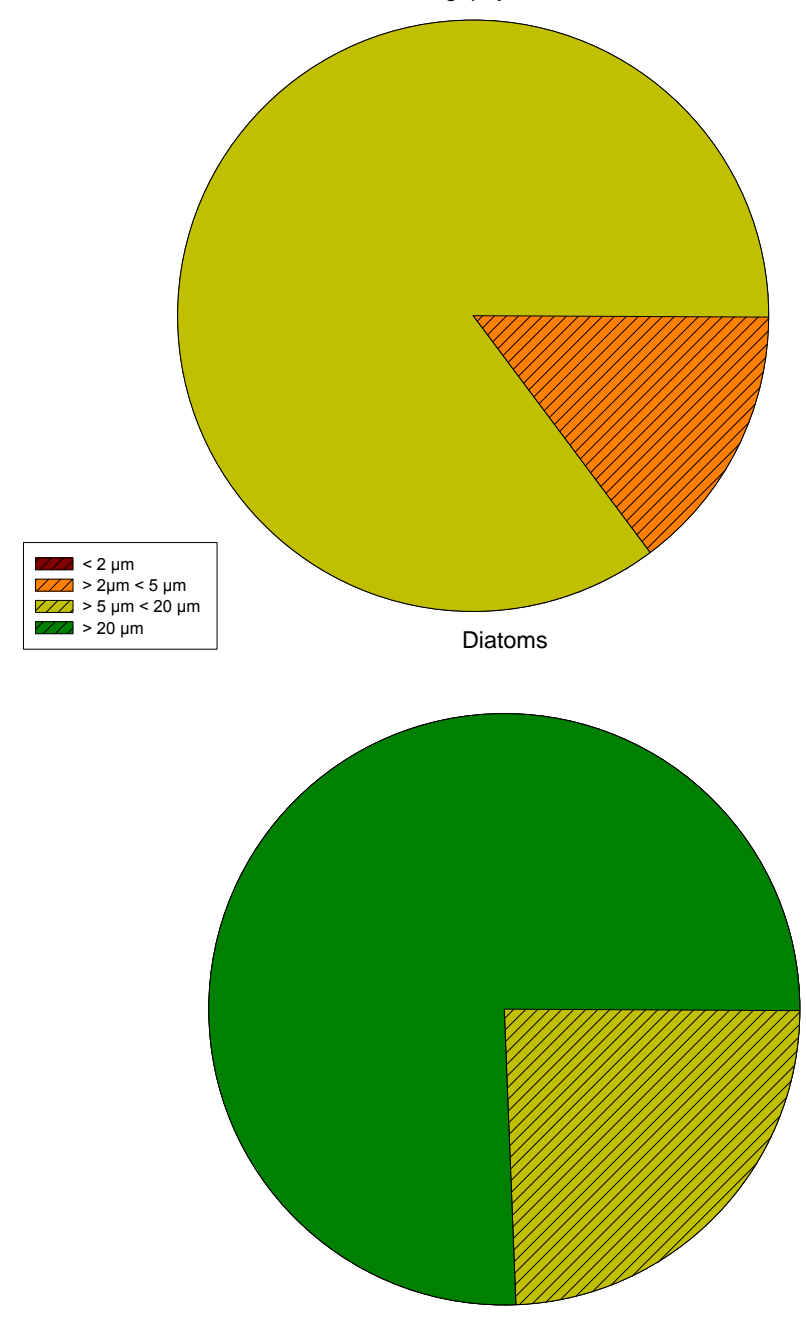

Haptophytes

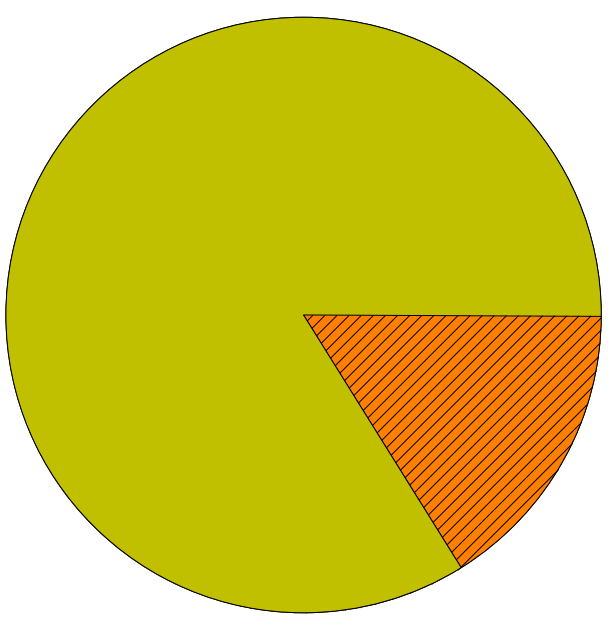

Cryptophytes

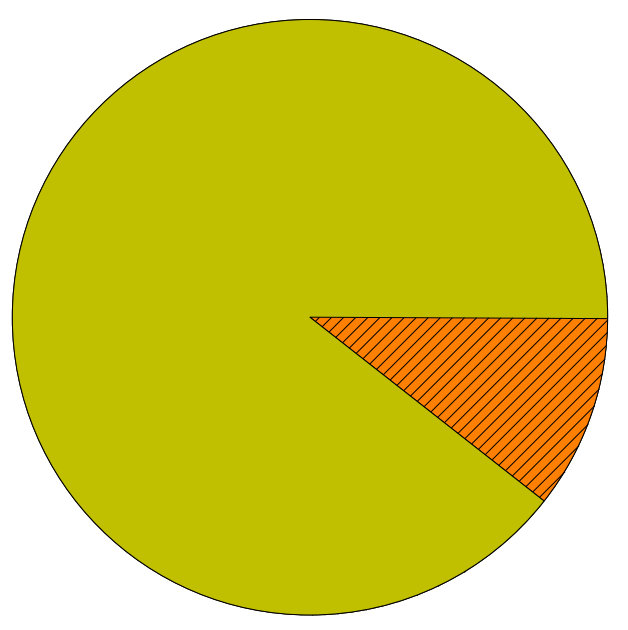

Chlorophyll

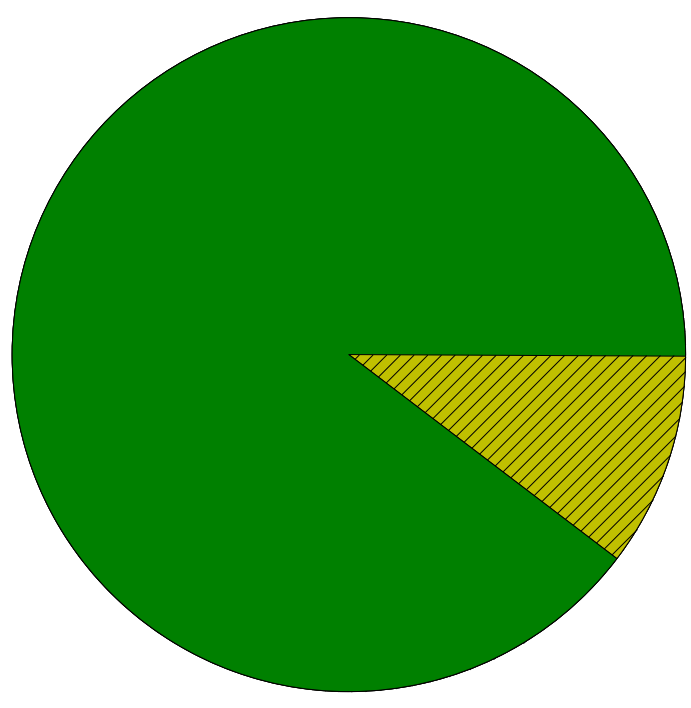



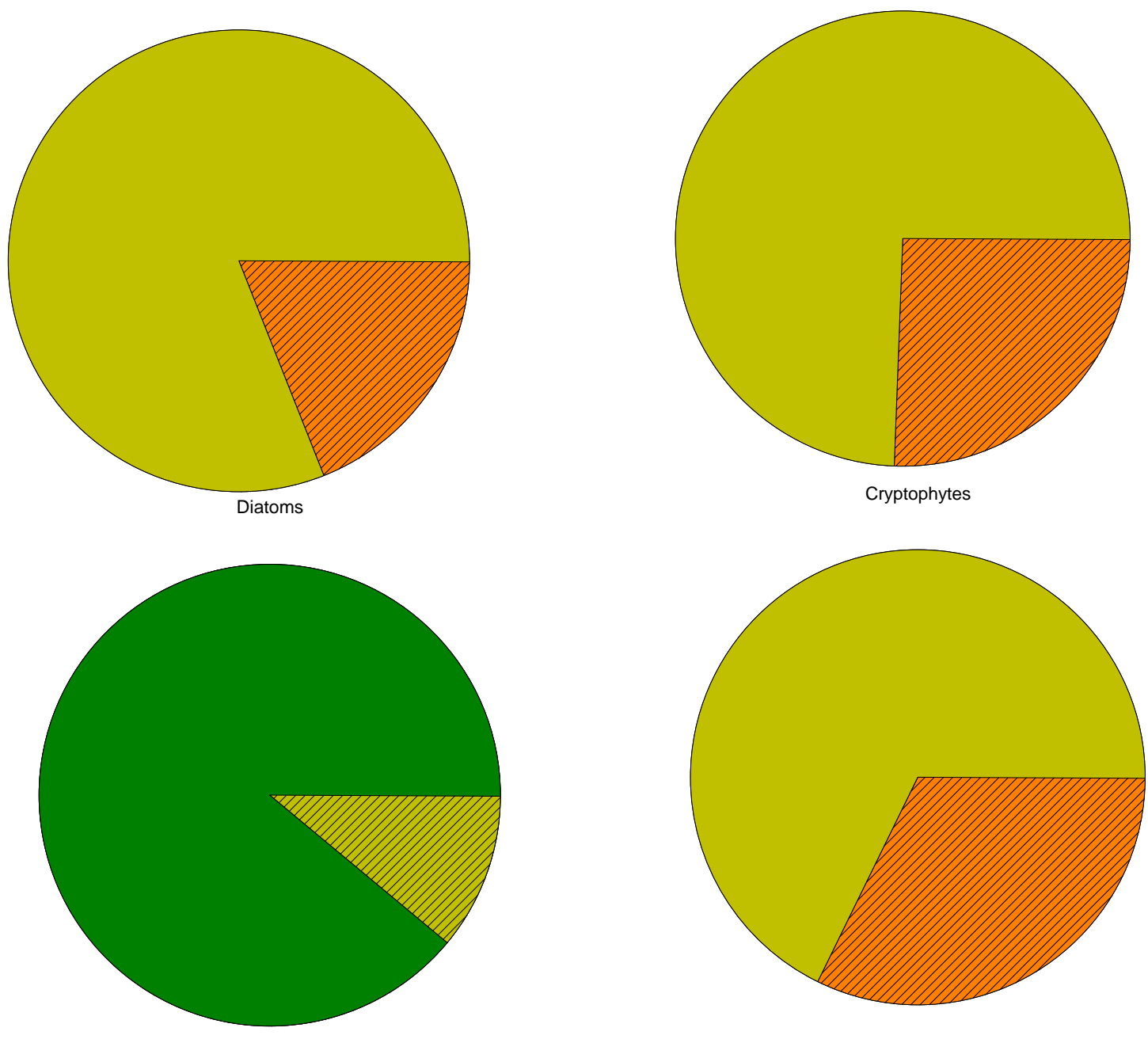

Chlorophyll

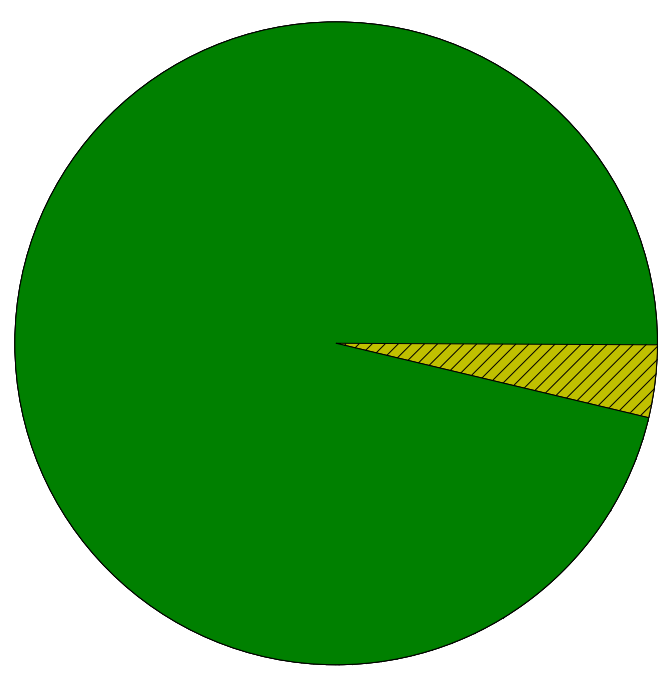




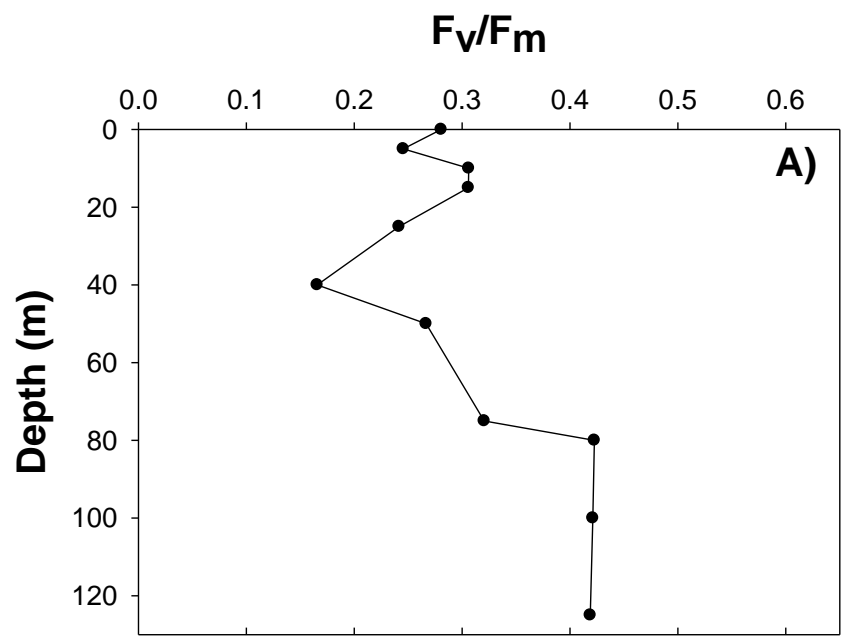

Minutes of survey

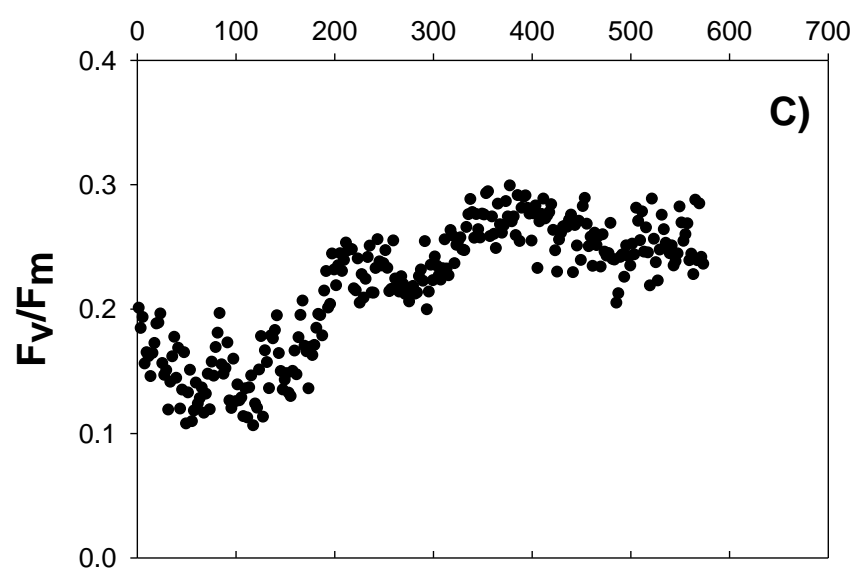

$\mathbf{F}_{\mathbf{V}} / \mathbf{F}_{\mathbf{m}}$

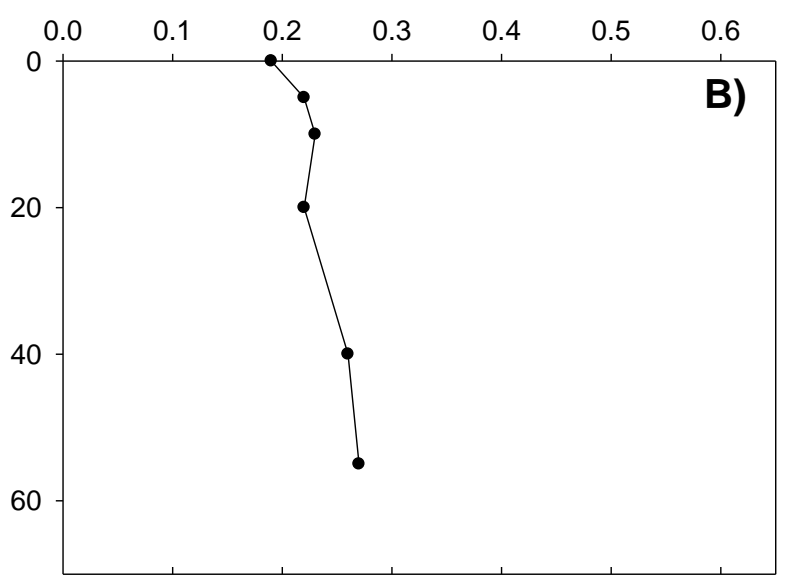

$\mathbf{F}_{\mathbf{V}} / \mathbf{F}_{\mathbf{m}}$

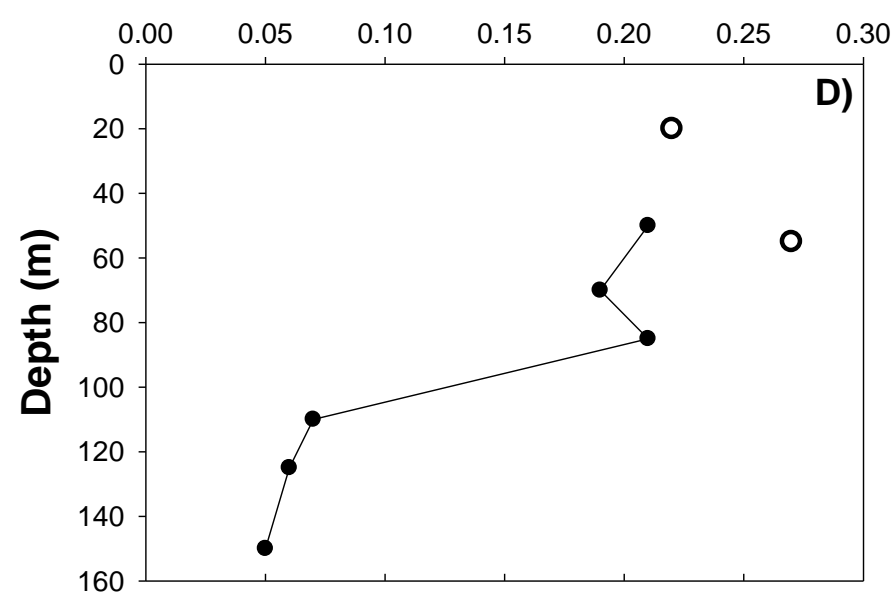




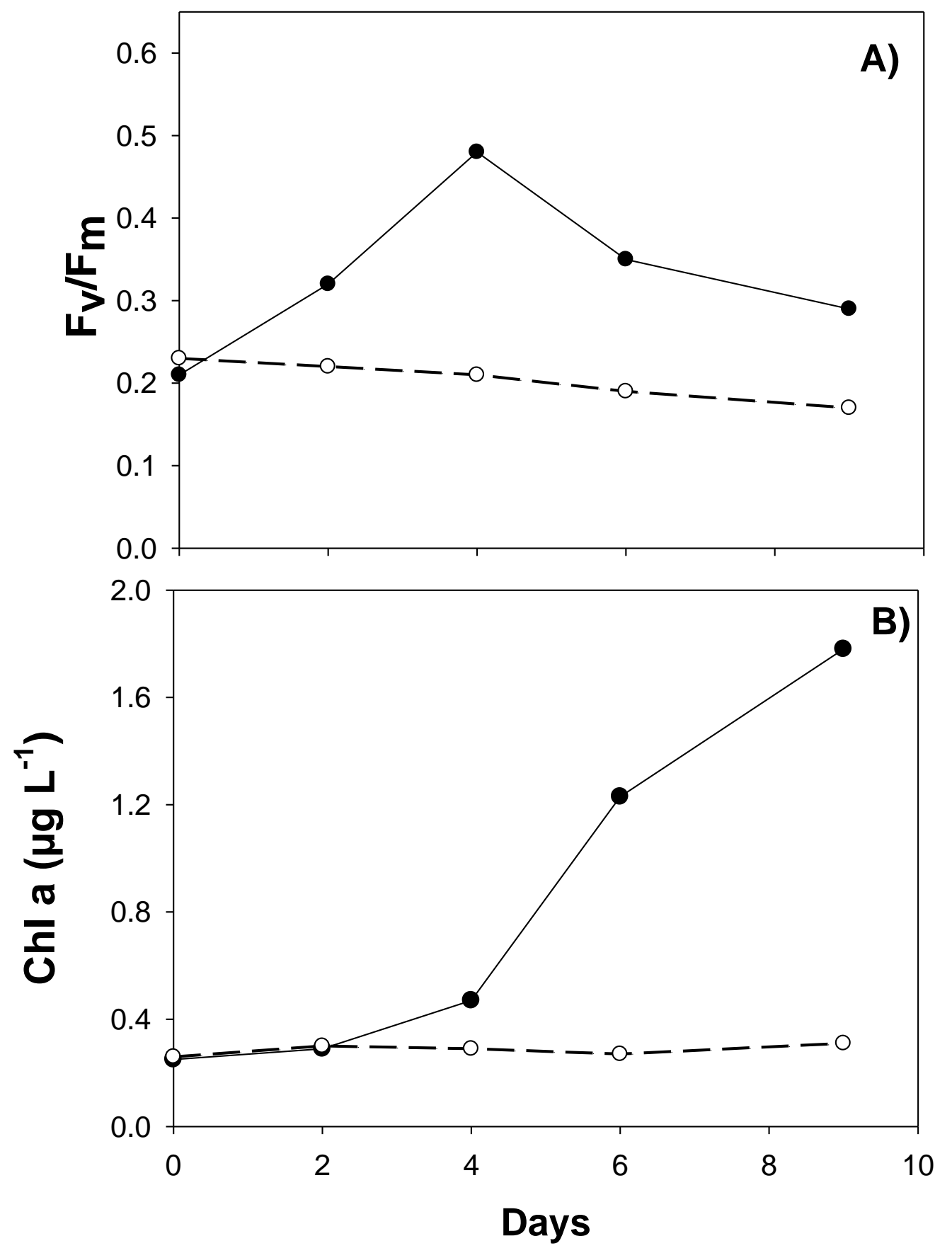




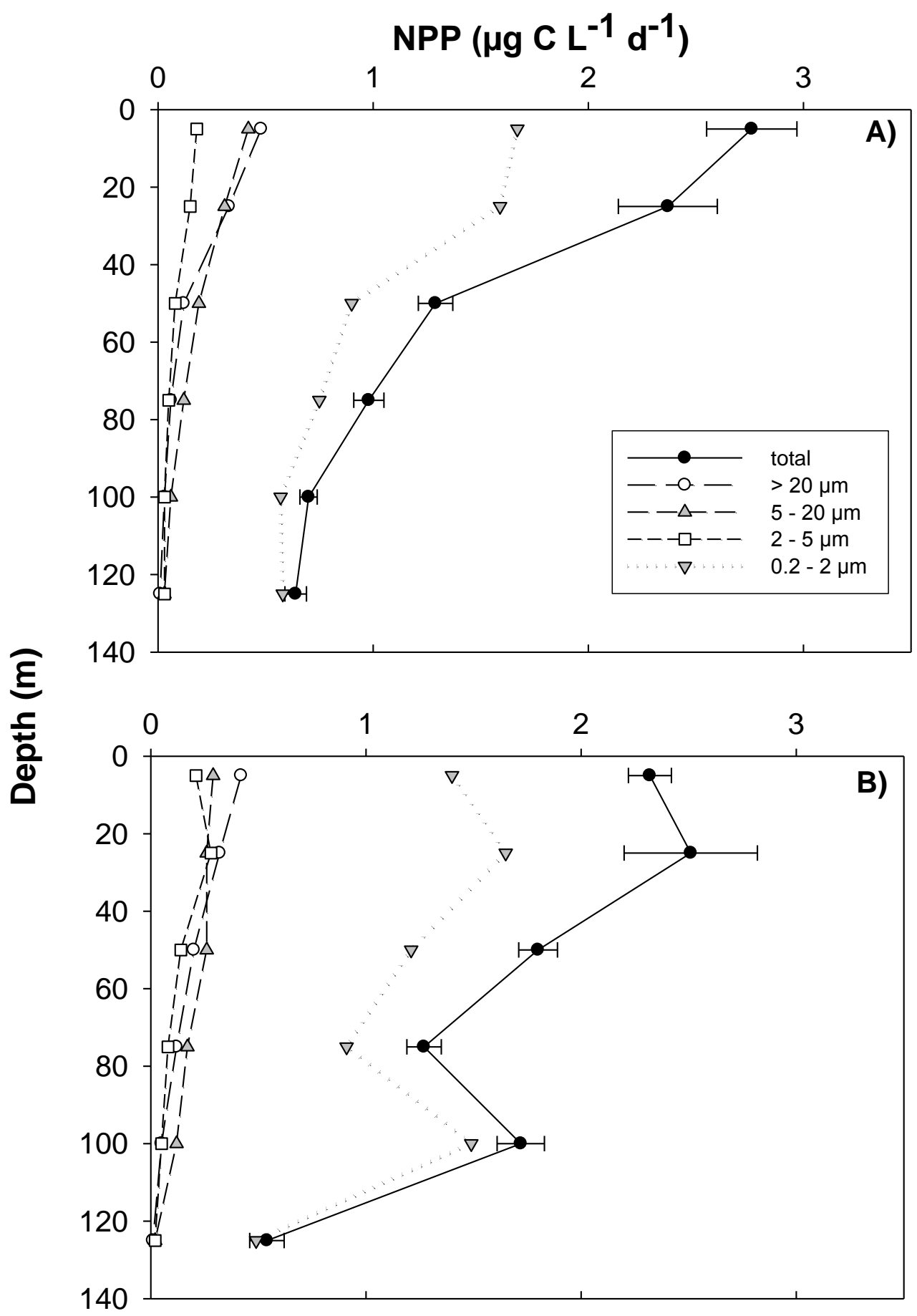




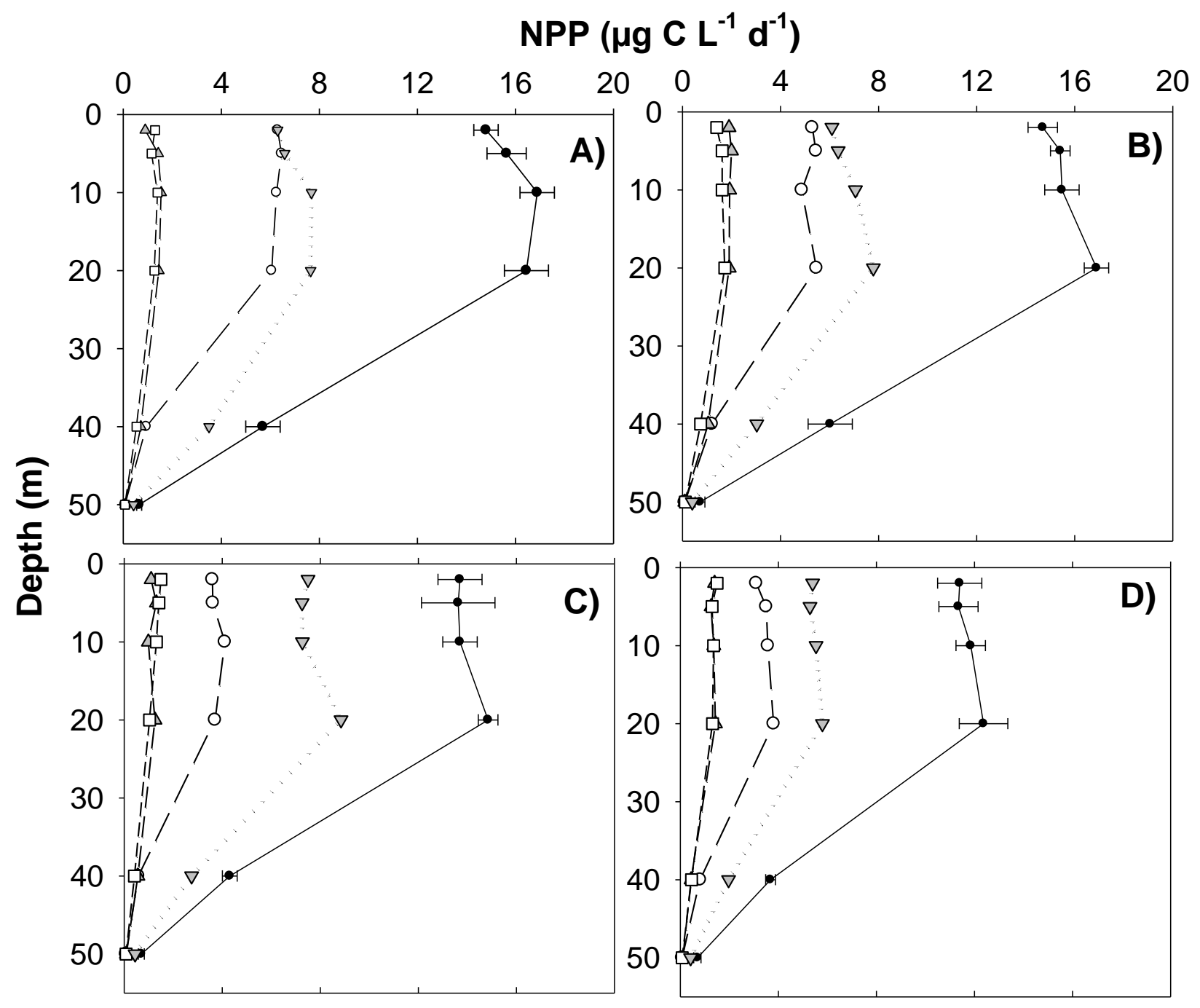




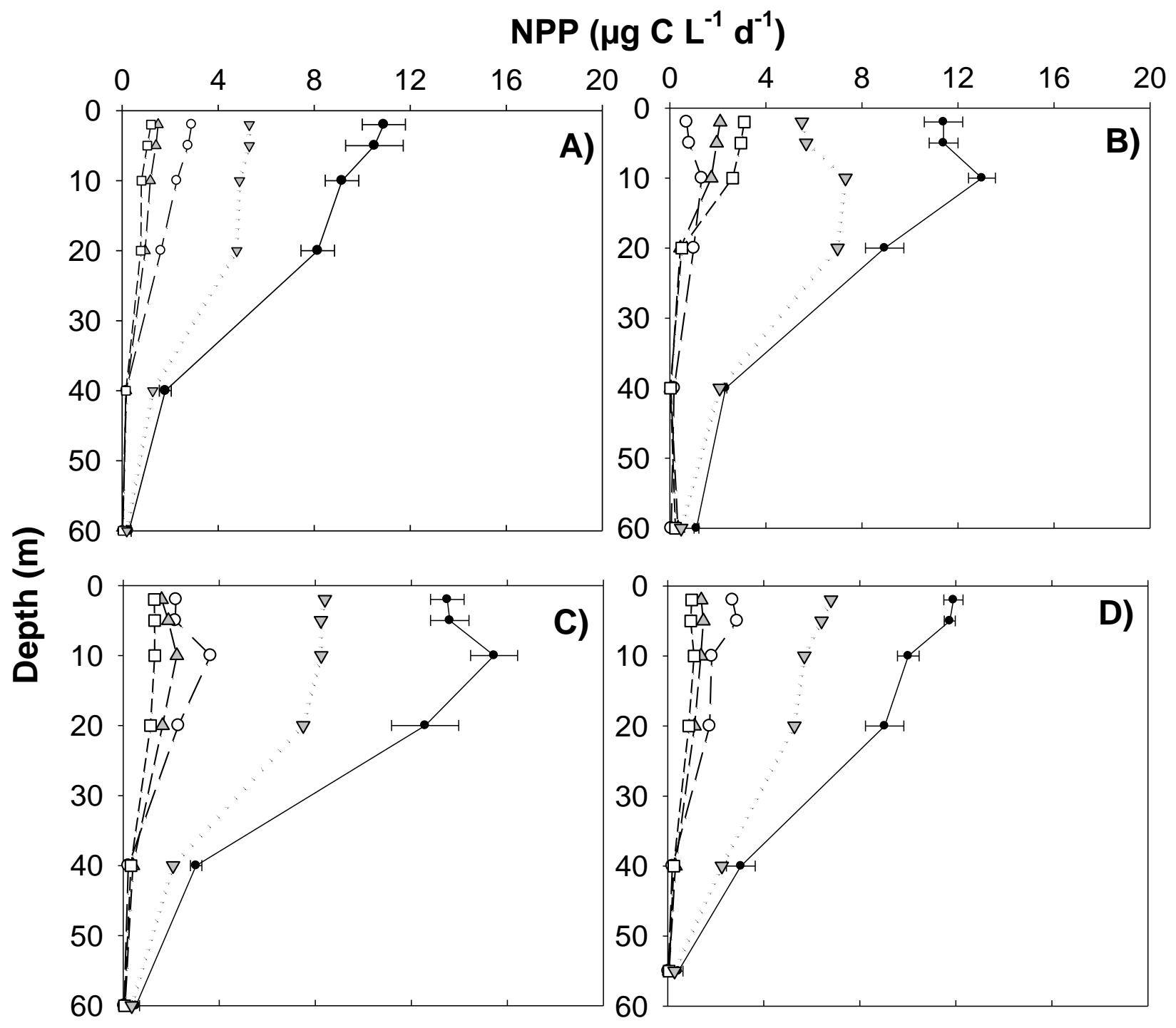




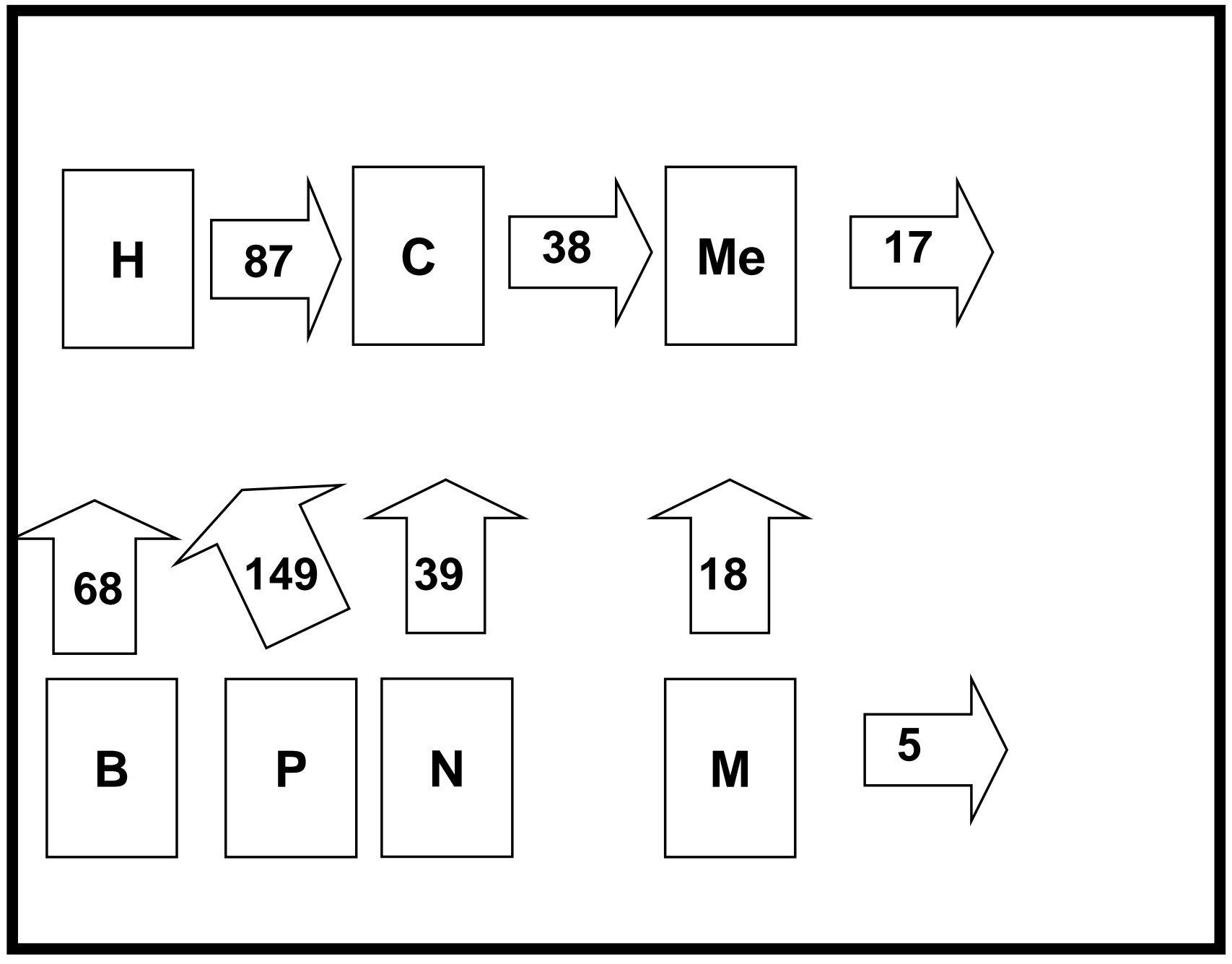




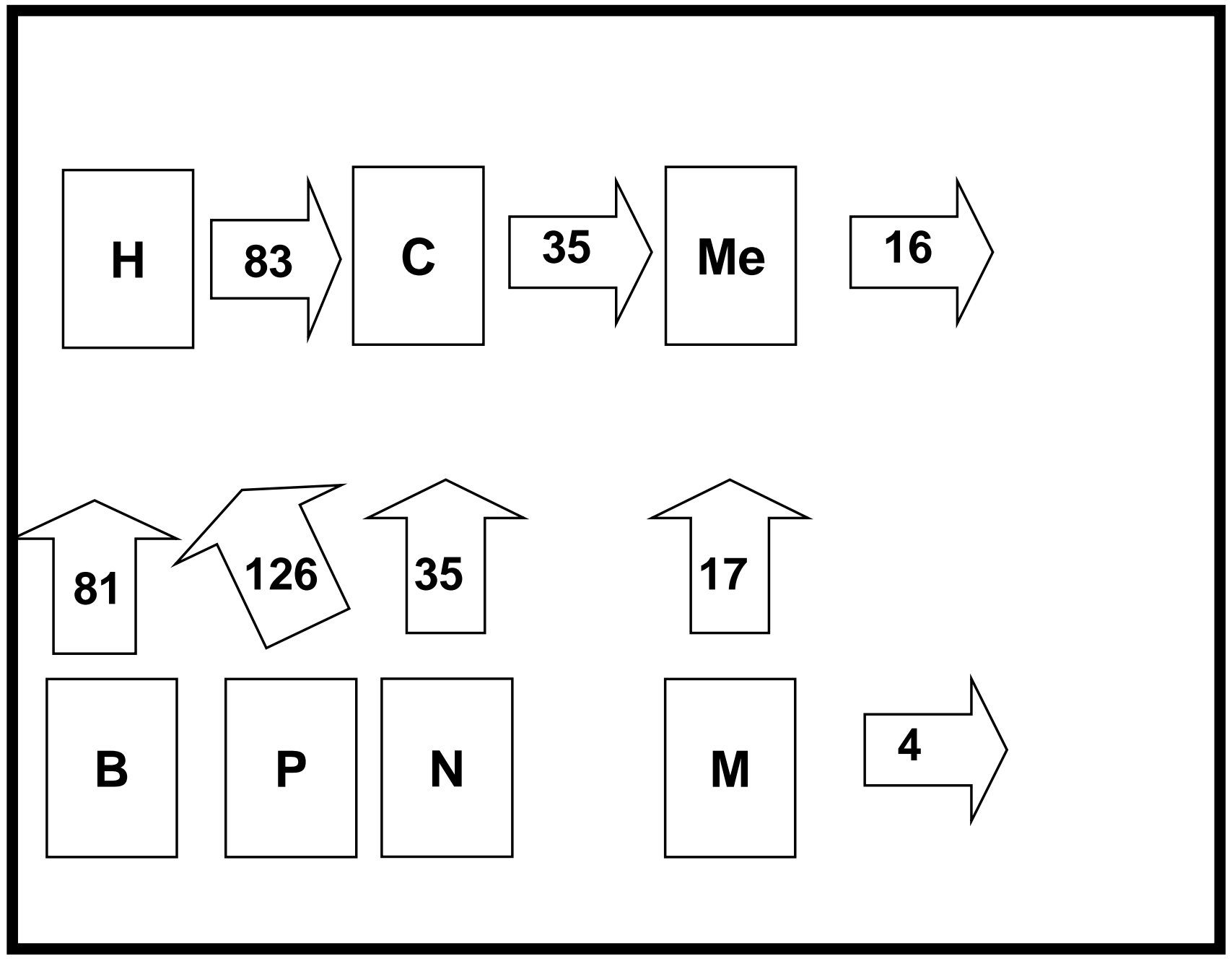




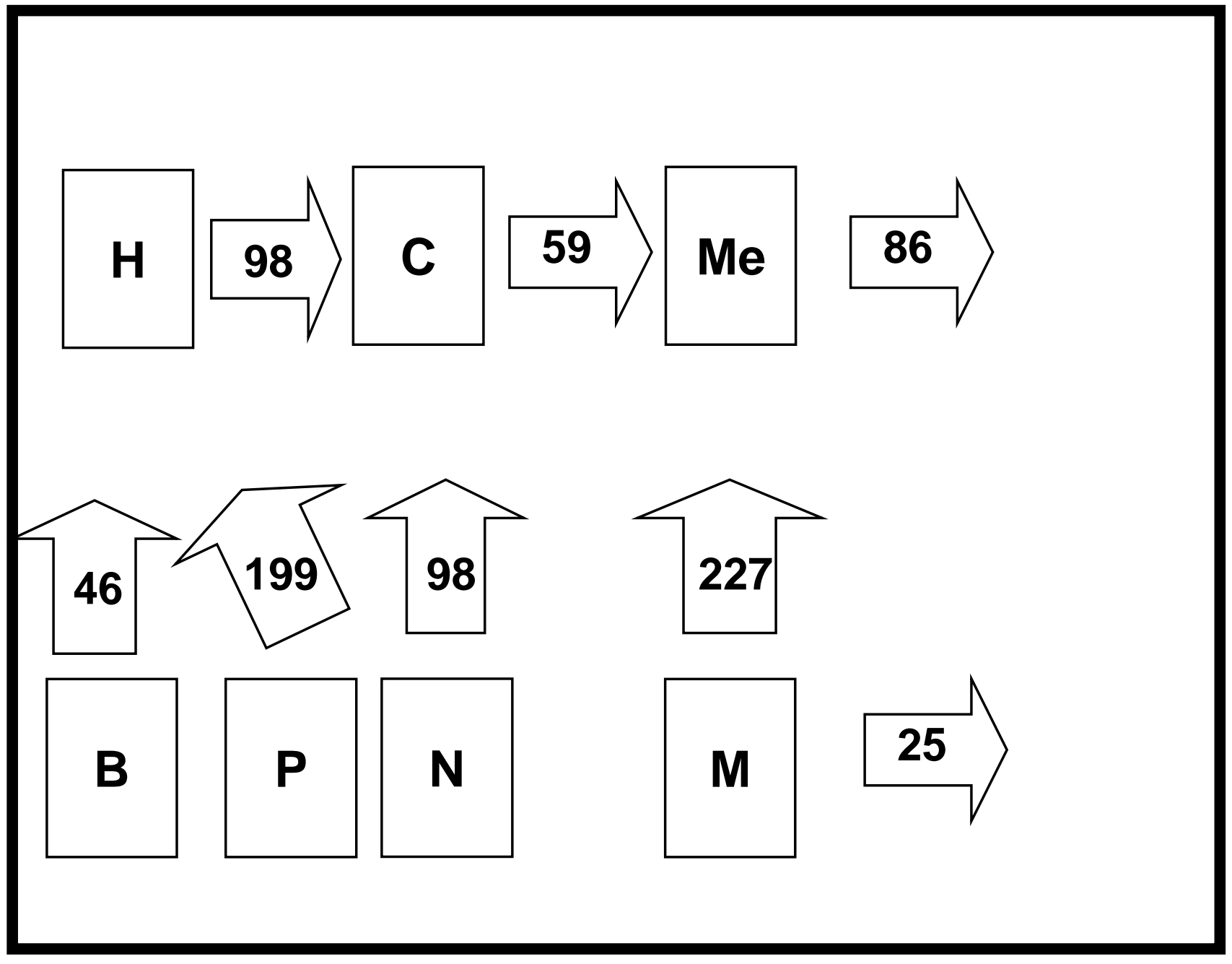




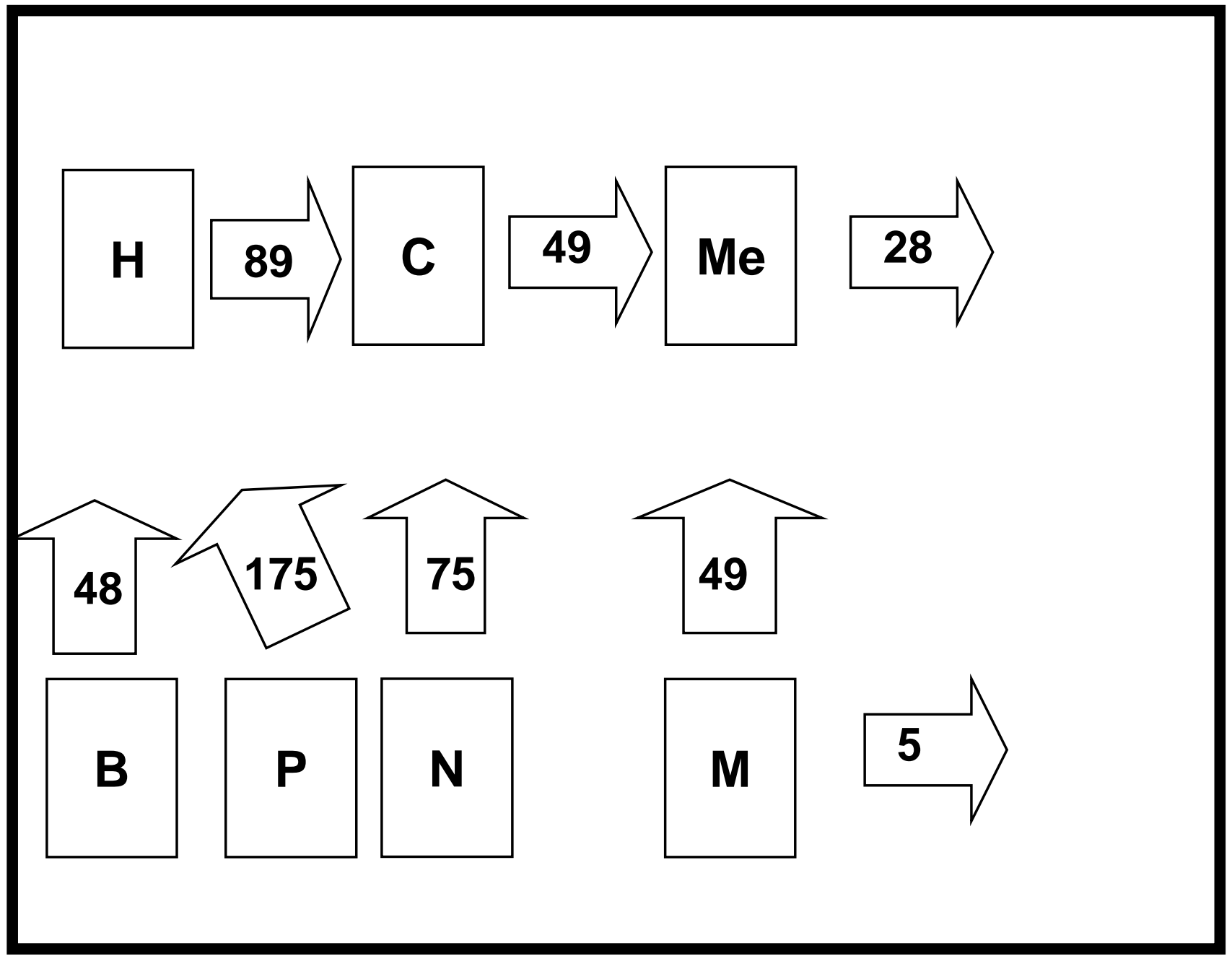

